DIW BERLIN

Discussion

Papers
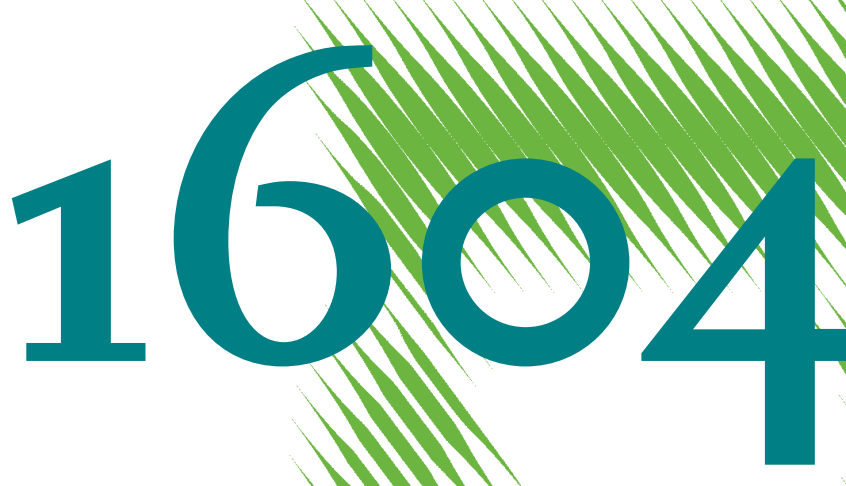

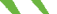

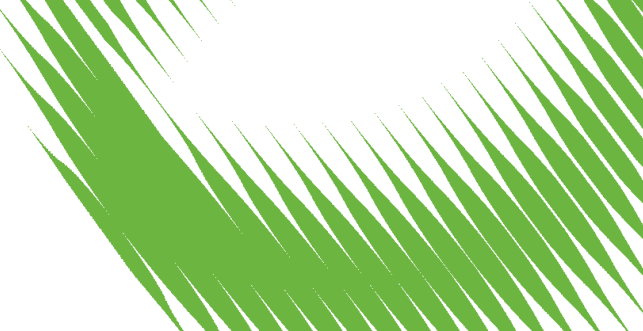

111

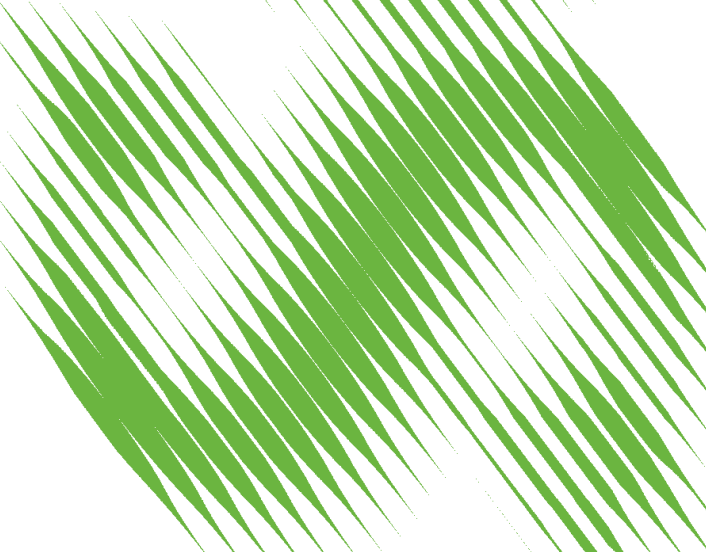

Testing Supply-Side Climate Policies for the Global Steam Coal Market - Can They Curb Coal Consumption? 
Opinions expressed in this paper are those of the author(s) and do not necessarily reflect views of the institute.

IMPRESSUM

(C) DIW Berlin, 2016

DIW Berlin

German Institute for Economic Research

Mohrenstr. 58

10117 Berlin

Tel. +49 (30) $89789-0$

Fax +49 (30) $89789-200$

http://www.diw.de

ISSN electronic edition 1619-4535

Papers can be downloaded free of charge from the DIW Berlin website:

http://www.diw.de/discussionpapers

Discussion Papers of DIW Berlin are indexed in RePEc and SSRN:

http://ideas.repec.org/s/diw/diwwpp.html

http://www.ssrn.com/link/DIW-Berlin-German-Inst-Econ-Res.html 


\title{
Testing Supply-Side Climate Policies for the Global Steam Coal Market - Can They Curb Coal Consumption?
}

\author{
Roman Mendelevitch ${ }^{a, b}$ \\ ${ }^{a}$ German Institute for Economic Research (DIW Berlin), Mohrenstrasse 58, 10117 Berlin, Germany \\ ${ }^{b}$ Workgroup for Economic and Infrastructure Policy (WIP), Berlin University of Technology, \\ Strasse des 17. Juni 135, 10623 Berlin, Germany; \\ rmendelevitch@diw.de, Tel. +49 30 89789-206
}

\begin{abstract}
The achieved international consensus on the $1.5-2^{\circ} \mathrm{C}$ target entails that most of current fossil fuel reserves must remain unburned. Currently, a majority of climate policies aiming at this goal are directed towards the demand side. In the absence of a global carbon regime these polices are prone to carbon leakage and other adverse effects. Supply-side climate policies present an alternative and more direct approach to reduce the consumption of fossil fuels by addressing their production. Here, coal as both, the most abundant and the most emissionintensive fuel, plays a pivotal role. In this paper, I employ a numerical model of the international steam coal market (COALMOD-World) to examine two alternative supply-side policies: 1) a production subsidy reform introduced in major coal producing countries, in line with the G20 initiative to reduce global fossil fuel subsidies; 2) a globally implemented moratorium on new coal mines. The model is designed to replicate global patterns of coal supply, demand and international trade. It features endogenous investments in production and transportation capacities in a multi-period framework and allows for substitution between imports and domestic production of steam coal. Hence, short-run adjustments (e.g. import substitution effects) and long-run reactions (e.g. capacity expansions) of exporting and importing countries are endogenously determined. Results show that a subsidy removal, while associated with a small positive total welfare effect, only leads to an insignificant reduction of global emissions. By contrast, a mine moratorium induces a much more pronounced reduction in global coal consumption by effectively limiting coal availability and strongly increasing prices. Depending on the specification of reserves, the moratorium can achieve a coal consumption path consistent with the $1.5-2^{\circ} \mathrm{C}$ target.
\end{abstract}

Keywords: Supply-side climate policy, coal markets, reserves, subsidy removal, International trade

JEL Codes: C72, H25, Q35 


\section{Introduction}

The COP21 Paris agreement has brought about a clear commitment to reduce anthropogenic greenhouse gas $(\mathrm{GHG})$ emissions to a level that will most likely keep the increase of global mean temperature below $2^{\circ} \mathrm{C}^{1}$ and striving for $1.5^{\circ} \mathrm{C}$. McGlade and Ekins (2015) estimate that achieving the $2^{\circ} \mathrm{C}$ target requires refraining from using a large share of current fossil fuel reserves but leaving them in the ground. Given its limited use for other than heat generation and resulting low economic value (Collier and Venables 2014) on the one hand and its abundance on the other hand, $82 \%-88 \%$ of current coal reserves need to be left unburned until 2050 (McGlade and Ekins 2015). The difference in the two numbers accounts for possible future use of Carbon Capture, Transport and Storage (CCTS), a technology which is currently not available at a demonstration scale ${ }^{2}$ and which has thus far not lived up to the high hopes put in it (Reiner 2016).

While there is consensus that reducing $\mathrm{CO}_{2}$ emissions and refraining from coal consumption are inseparably linked, there is major inertia hindering the transformation of the energy system. Incumbent industries in countries that have a long history of using coal as the primary fuel in their energy mix are reluctant to adapt their business models and to bring forward decarbonization (Fulton, Spedding, et al. 2015). Although a large number of demand-side policy instruments exist (see section 2 ) they are not sufficient to achieve required emission reductions. In fact, the IEA World Energy Outlook New Policies Scenario (IEA 2015a) which assumes the implementation of most of currently announced climate policies, including most of the Intended Nationally Determined Contributions (INDCs) ${ }^{3}$ under the United Nations Framework Convention on Climate Change (UNFCCC), still projects a $15 \%$ increase of annual global emissions until 2040. Coal production is expected to increases by $18 \%$ during the same period. Even though the scenario fails to incorporate some of the major trends with respect to the restructuring of global energy systems ${ }^{4}$, the general conclusion that currently discussed policies will not lead to a deep decarbonization, is still valid.

\footnotetext{
${ }^{1}$ Hereafter referred to as the " $2^{\circ} \mathrm{C}$ target".

2 The only existing CCTS infrastructure at Boundary Dam in Saskatchewan, Canada (in operation since October 2014), used the $\mathrm{CO}_{2}$ for enhancing oil recovery and thus cannot be considered an emission reducing project. See Oei, Herold, and Mendelevitch (2014) and Hirschhausen, Herold, and Oei (2012) for more details on CCTS.

${ }^{3}$ With one major exemption: INDCs submitted by India are not fully incorporated but rather the original target of $100 \mathrm{GW}$ of solar PV installed until 2022 is reduced to $40 \mathrm{GW}$ (IEA 2015a, 498).

${ }^{4}$ Namely, the scenario misses current developments in the U.S., China, and the EU. As an example, important regulations like the Clean Power Plan in the U.S. (EIA 2015b) are incorporated but not logically extrapolated to 2040. Moreover, the peak in coal consumption (NBSC 2015) and a moratorium on new coal power plants and mines in China are not accounted for (see The State Council of the People's Republic of China (2016): "Coal Capacity Guideline Issued." February 5. http://english.gov.cn/policies/latest_releases/2016/02/05/content_281475284701738.htm., and Boren (2016): "China Stops Building New Coal-Fired Power Plants." Energydesk. March 24. http://energydesk.greenpeace.org/2016/03/24/china-crackdown-new-coal-power-plants/). Likewise, the ban of coal from the energy mix in a number of European countries like in the UK is not included in the central scenario (cf. Rudd (2015): "Amber Rudd's Speech on a New Direction for UK Energy Policy - Speeches - GOV.UK." Gov.uk. November 18. https://www.gov.uk/government/speeches/amber-rudds-speech-on-a-new-direction-for-ukenergy-policy.).
} 
While most of these policies are directed towards the demand-side of fossil fuels, many scholars argue that supply-side policies hold promise to be more effective in achieving desired emission reductions (see e.g., Lazarus, Erickson, and Tempest 2015). The contribution of this paper is to quantify the effects of two supply-side policies that are currently discussed to complement the wide range of demand-side policies in further reducing fossil fuel consumption: The first instrument is a removal of coal production subsidies to reveal the "real" cost of coal supply. This policy measure can be seen as one part of the international strive to phase out fossil fuel subsidies, as agreed on, e.g., by the G20 (2009). This paper contributes to the literature by summarizing available information on coal production subsidies in the major producing countries and providing an estimate on the mark-up resulting from removing respective subsidies. The level varies significantly between $0.1 \mathrm{USD} / \mathrm{t}$ in Poland and 3.4 USD/t for coal from the U.S. Powder River Basin (PRB). Depending on the producer this corresponds to less than $1 \%$ of production cost for Poland and South Africa, up to $34 \%$ for PRB coal.

The second policy examined in this chapter is a permanent moratorium on new coal mines, as suggested by President Tong of the Republic of Kiribati (Tong 2015) and supported by many scholars (see section 4). This policy could be implemented in various ways, e.g., by stopping to issue licenses for new mining projects and by not renewing those of inactive projects. To assess the consequences of such an intervention detailed information on existing mining operations is a crucial issue. There is a lack of publically available data, therefore I compile an own data set of reserves in operating mines based on publically available information. Based on this data, about one third of global reserves reported in international surveys (e.g., BGR 2015) are located in currently active mines. This share is largest in South Africa (69\%) and smallest in the U.S. (8\%).

Taking these two policies as scenarios, the paper uses a comprehensive model of the world steam coal market COALMOD-World (see Mendelevitch et al. (forthcoming) for a detailed description of the model) to assess their effects on patterns of global steam coal trade, prices and $\mathrm{CO}_{2}$ emissions from coal consumption as well as their distribution effects. The two policies are assumed to be introduced in 2020. Although, generally the model works with perfect foresight, the policies are implemented in a way to ensure no anticipation effects. The subsidy removal policy leads to an insignificant reduction in $\mathrm{CO}_{2}$ emissions of, on average, $82 \mathrm{MtCO}_{2}$ per year but still leaves a gap of $3.5 \mathrm{GtCO}_{2}$ to be addressed by other measures to achieve emission reductions consistent with a $2^{\circ} \mathrm{C}$ target. Nevertheless, the policy generates considerable additional income for emerging countries (China 31.5 bn USD, India 8.1 bn USD, Indonesia 7.2 bn USD) in the period 2020 to 2040 . This additional income can be used to finance additional measures to reduce $\mathrm{CO}_{2}$ emissions. Moreover, the policy generates additional revenue for infra-marginal producers that benefit from an average increase of coal prices by about $1 \%$ per year from 2020 to 2040, compared to the reference case. By contrast, a global moratorium on new mining projects could be a major contribution to closing the gap towards a coal consumption that is consistent with the $2^{\circ}$ target. In fact, the "Mine Moratorium" scenario exceeds reductions implied by the WEO 450ppm scenario. The supply path in this scenario is, however, in line with McGlade and Ekins' (2015) calculations on "unburnable" coal reserves. These are required to stay in the ground in order to achieve the $2^{\circ} \mathrm{C}$ target, without relying on CCTS. 
The results of the two scenario analyses can be understood as a benchmark for the maximum ability of these policies to close the gap between the current consumption path and one that is consistent with the $2^{\circ}$ target. The partial equilibrium setting of the underlying model does not specify the substitute that is used to compensate reduced steam coal consumption and therefore does not account for potential $\mathrm{CO}_{2}$ emissions from alternative sources. Also the model does not take into account welfare effects of recycling funds freed up by the removal of subsidies on coal production. (see Mendelevitch et al. (forthcoming) for a discussion of model limitations).

The remainder of the paper is organized as follows: the next section presents an overview of demandside climate policies currently implemented and supply-side policies currently discussed. The subsequent section takes a closer look at coal producer subsidies and discusses findings from literature on their removal, and present own calculations on effects of subsidy removal. Section 4 discusses a moratorium on new coal mines as a potential supply side climate policy and details coal reserves in operating mines for the largest producers of steam coal. Furthermore, it gives a quantitative assessment of effects of a mine moratorium on the international steam coal market based on different specifications. Section 5 concludes.

\section{Instruments of climate policy}

One common metric to categorize climate policies accounts for the side of the market for emissionintensive goods (in the scope of this paper steam coal) that they address: those policies targeting the consumers are referred to as demand-side policies, while those addressing the production are referred to as supply-side policies (Kolstad et al. 2014, 364). Each policy has its specific advantages and disadvantages. Typical policy evaluation criteria assess the efficiency, the effectiveness, and the feasibility of a policy intervention (Perman et al. 2012). The Grantham Research Institute maintains a database of global climate legislation which details different policies that have been implemented (Grantham Research Institute 2015a). ${ }^{5}$

\subsubsection{Demand-side policies}

Demand-side policies for reducing $\mathrm{CO}_{2}$ emissions have received the most attention in the academic literature and have been most commonly introduced in practice. Carbon pricing instruments place an explicit price on emissions - either directly, as a carbon tax, or indirectly, through a cap-and-trade scheme (OECD 2013). Such instruments have been implemented (or are scheduled to be implemented) in 39 countries, and at the jurisdictional level in a further three countries (Kossoy et al. $2015,22)$.

There are many other policy instruments which generate an implicit carbon price through regulatory intervention. Prominent examples are emissions performance standards, minimum flexibility requirements, renewable portfolio obligations (see Oei et al. (2014) for a discussion of regulatory options to reduce $\mathrm{CO}_{2}$ emission in the power sector. Other demand-side policies include measures

\footnotetext{
${ }^{5}$ The following two sections are based on earlier work from Collins and Mendelevitch (2015).
} 
that promote energy efficiency and reduced energy consumption (as discussed in articles in Economics of Energy \& Environmental Policy Symposium on "Energy Efficiency": Gandhi et al. 2016; R. Hahn and Metcalfe 2016; Rosenow et al. 2016; Houde and Spurlock 2016).

In the absence of full participation in a global climate policy, demand-side policies are susceptible to carbon leakage: emissions-intensive activities shift to non-participating countries, such that emissions reductions in the participating countries are partly offset by emissions increases in the nonparticipating countries (see e.g. Felder and Rutherford 1993; Sinn 2008). Richter (2015) provides an overview of empirical studies of the carbon leakage effect, which is undisputed in existence, but controversial in magnitude.

Moreover, a "green paradox" has also been theorized, where the expectation of future demand-side policies could induce resource producers to increase their present rates of extraction in order to maximize net present value (Sinn 2015). For coal, Haftendorn, Kemfert, and Holz (2012) suggest that in practice the green paradox may not be relevant, while Bauer et al. (2013) find a short term reduction of coal prices due to stringent climate policy. Gerlagh (2011) argues that the green paradox relies on oversimplified model assumptions with total depletion of the resource and high substitutability between energy fuels. Hoel (2012) adds that the paradox is only prevailing if policies target low cost suppliers while it is absent if it affects mainly high-cost suppliers of fossil fuel.

\subsubsection{Supply-side policies}

Supply-side policies represent an alternative and more direct route to address negative effects of fossil fuel combustion. One important factor to consider when deciding between a demand-side and a supply-side policy is the ratio of demand vs. supply elasticity, as it drives the leakage risk for the respective policy. Lazarus, Erickson, and Tempest (2015) calculate this ratio for different fuels and regions based on various studies and find mixed evidence for supply-side and demand-side leakage risk for coal. Collier and Venables (2014) argue that for coal, supply-side policy may be less prone to leakage, and Hoel (2013) suggests the green paradox could be eliminated with a supply-side policy that targets high-cost coal deposits. Lazarus, Erickson and Tempest conclude that such climate policies are more likely to limit over-supply of fossil fuels and associated "carbon lock-in" effects.

One type of supply-side policy acts to directly remove coal reserves from production - whether to a partial extent (focusing on high-extraction-cost reserves for economic efficiency) (Harstad 2012), or to a further extreme, the progressive closure of the entire coal industry (Collier and Venables 2014). Another type of supply-side policy is a depletion tax (or alternatively, a depletion quota), which is analogous to the demand-side policy of a carbon tax (or for a depletion quota, a carbon budget). For instance, in Richter, Mendelevitch, and Jotzo (2015) propose a tax on the energy content of steam coal, levied by a coalition of major coal exporters. A supply-side policy for coal could also take the form of an export-licensing regime adopted by a coalition of major coal exporters, in analogy to the existing safeguards regime for uranium exports; based on the reasoning that the regulation of commodity exports on the basis of their harmful or unethical end use is a widely accepted principle, and should be extended to coal (A. Martin 2014). Lazarus, Erickson, and Tempest (2015) provide a comprehensive taxonomy of supply-side climate policies. 
To date, there has been limited experience with the implementation of supply-side policies. The concept of preserving fossil fuel reserves has some precedent in the Yasuni-ITT Initiative, which was a proposal by the Ecuadorian government in 2007 to preserve oil reserves, but ultimately was not carried through (P. L. Martin 2014). A recent initiative that directly targets future coal supply is the "No New Coal Mines" campaign. It was started by the President of Kiribati who urged the leaders of the world to support this call for a moratorium on the opening of new and the expansion of existing mines (Tong 2015). This initiative is supported, inter alia, by the Obama administration (Warrick and Eilperin 2016) and by the Australia Institute (Denniss 2015b) which argues in favor of a global moratorium on new coal mines. Another supply-side policy which is broadly discussed at least since 1997 (cf. World Bank 1997) but only fragmentally implemented is a removal of fossil fuel subsidies. Both, the subsidy removal and the mine moratorium policy and their application to the steam coal market are discussed in detail in the two subsequent sections.

\section{A production subsidy reform as a supply-side climate policy}

Influential country groups like the G20 (2009), APEC (2010), Friends of Fossil Fuel Subsidy Reform (GSI 2011), and UN Secretary General's High-Level Panel on Global Sustainability (2012), have all committed to phasing out fossil fuel subsidies. Sustainable Development Goals, adopted in September 2015 by the UN (2015) include a target focused on the rationalization of inefficient fossil fuel subsidies. To improve the understanding of the range and magnitude of fossil fuel subsidies in different countries, the Organization for Economic Co-operation and Development (OECD 2015b) conducted a comprehensive study. It counts almost 800 individual policies that support the production or consumption of fossil fuels in OECD countries and six large partner economies (Brazil, the People's Republic of China, India, Indonesia, the Russian Federation, and South Africa) with an overall value of 160-200 bn USD annually over the 2010-14 period. It estimates annual budgetary support and tax expenditure on coal subsidies to account for around 12 bn USD. A study by Ecofys which includes additional subsidy categories, found that coal subsidies in the EU-28 accounted for 10 bn EUR in 2012 (Ecofys 2014). Updating a global study by the International Monetary Fund (Clements et al. 2013), Coady et al. (2015) find fossil fuel subsidies accounting for $6.5 \%$ of global GDP (with $3.4 \%$, or 2,530 bn USD originating from coal subsidies, with the major contribution of 2,506 bn USD due to global warming and local pollution externalities).

In developing economies, subsidy reforms are opposed by rent-seeking of incumbent stakeholders and divergence of interest between provincial and national governments (Dansie, Lanteigne, and Overland 2010). Often starting from a poor service level, governments are afraid to take unpopular decisions and induce social unrest. Citizens first need to be persuaded that the withdrawn support will be used in a welfare increasing way elsewhere.

Koplow (2015) provide a taxonomy of subsidies in energy industries. While they are commonly applied on both the demand and the supply side of fossil fuels, their removal may have very different effects and consequences depending on whether it affects producers or consumers. There is a large strain of literature analyzing the distributional incidence, induced emissions, and other distorting effects of 
demand-side fossil fuel subsidies (e.g. Arze del Granado, Coady, and Gillingham 2012; Dartanto 2013; Burniaux and Chateau 2014; Lin and Ouyang 2014; Schwanitz et al. 2014; Durand-Lasserve et al. 2015). Merrill et al. (2015) provide an overview of models examining the effect of fossil-fuel subsidy reforms on greenhouse gas emissions.

In this paper, I want to concentrate on the implications of removing financial benefits granted to fossil fuel producers, and more specifically, coal producers. The removal of production subsidies for coal production can work as an effective supply-side climate policy. Such a policy comes with a doubledividend of removing heavy burdens from public budgets and reducing GHG emissions. Additionally, it can prevent carbon look-in by reducing capital-intensive investments from state-owned and international investors (Bast et al. 2015).

\subsection{Definitions and data sources}

Article 1 of the WTO "Agreement on Subsidies and Countervailing Measures" (WTO 1994) defines subsidies as a financial contribution of a government or a public body that is directed towards a company or industry and involves i) direct transfer of funds, ii) foregone revenue (e.g., taxation below benchmark level) iii) provision of goods and services below market value, or iv) provision of funds or price support through indirect measures. This definition is non-judgmental on whether the measure is for some reason justified or efficient. Three major sources build on this definition and consistently estimate energy subsidies on a disaggregated level, but employ two contrary approaches for assessing the respective subsidy level. The IEA's ${ }^{6}$ definition centers on lowering costs or raising prices in a way that is beneficial for producers or consumers. The $\operatorname{OECD}^{7}(2015 \mathrm{~b})$ uses a similar definition but adds a reference to market levels. The IMF's ${ }^{8}$ definition also distinguishes between pretax and post-tax subsidies, where the latter benchmarks to a price that also includes a "pigouvian" tax component correcting for externalities (see Figure 1 for an illustration of the different definitions, as well as Beaton et al. (2013) for a further discussion of different definitions of subsidies).

Bárány and Grigonytè (2015) and Kojima and Koplow (2015) provide a comparison of the different methodologies to assess the magnitude of fossil fuel subsidies. The methodology used by IEA is the price-gap approach, which compares the end-user price to a reference price comprising free-on-board (FOB) costs, cost of shipping plus margins and taxes. The OECD method is based on the inventory approach, which concentrates on budgetary support and tax expenditures that entail merits for producers or consumers of fossil fuel, either relative to other activities or products, or in absolute terms. The IMF has adopted the price-gap approach in order to estimate pre-tax subsidies. Post-tax subsidies compare actual consumer prices with supply cost plus the efficient level of taxation which includes externalities and a fair consideration of margins. Due to these methodological differences IMF

\footnotetext{
6 See OECD/IEA (2016) for the exact definition. The IEA subsidy dataset is available at: http://www.worldenergyoutlook.org/media/weowebsite/2015/Subsidies20122014.xlsx.

7 See OECD (2015b) for the exact definition. The OECD subsidy dataset is available at: http://www.oecd.org/site/tadffss/.

8 See Coady et al. (2015) for the exact definition. The IMF subsidy dataset is available at: http://www.imf.org/external/np/fad/subsidies/data/codata.xlsx.
} 
subsidy estimates are considerably higher than those published by IEA or OECD, as they also account for inefficient taxation of externalities (e.g. $\mathrm{CO}_{2}, \mathrm{NO}_{x}$ emissions and local air pollution).

As neither the IMF data (IMF 2015) nor the IEA database (IEA 2016) distinguish between production and consumption subsidies, they cannot be used in this analysis. To the contrary, the method employed by the OECD is much more suitable, as it explicitly provides budgetary items that can be directly assigned to coal producers and their production costs. Where available, I use data from the OECD (2015a) and from ODI (2015c) that extends the effort undertaken by the OECD (2015a) and provide a detailed list by subsidy type, jurisdiction, fuel, and fuel chain stage. Import tariffs, like in the case of China (cf. Xue et al. 2015), constitute an indirect subsidy to domestic producers by lowering their exposure to competition on the world market. As the model framework used in this paper does not account for this kind of market distortion, they are excluded from the analysis.

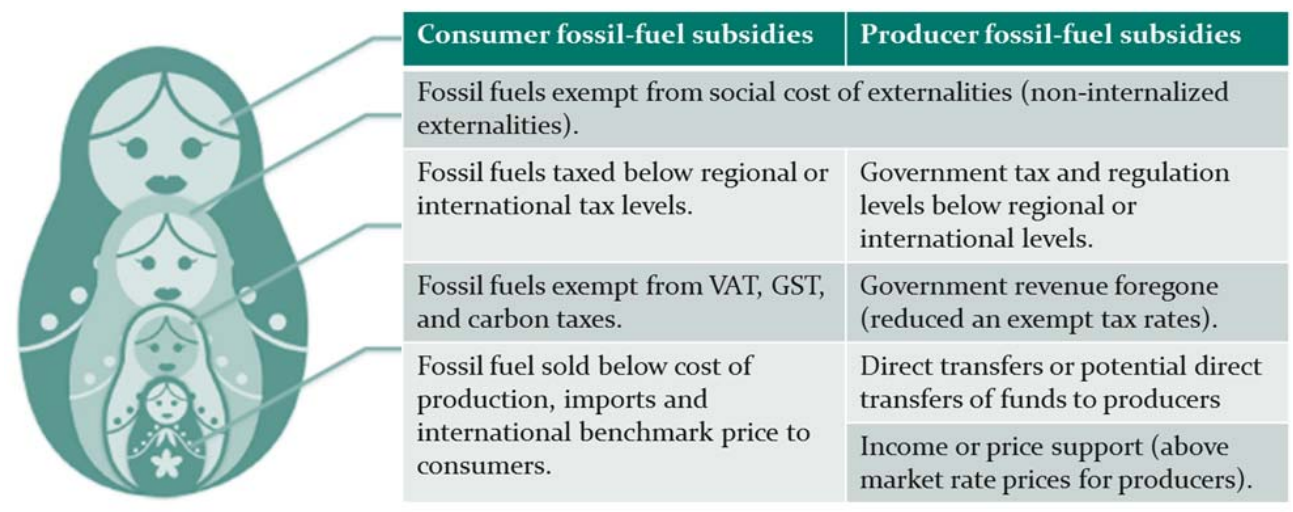

Figure 1: Illustration of different definitions of fossil fuel subsidies as a nested doll.

Source: Adapted from Merrill (2014).

\subsection{Findings from literature on coal production subsidies}

While many studies look into the effect of removing subsidies for all fossil fuels (see e.g. Schwanitz et al. 2014; Burniaux and Chateau 2014), there is only sparse literature on the effects of removing coal subsidies in particular. Anderson and McKibbin (2000) use the general equilibrium framework CCubed to assess the economic effects of removing production and consumption subsidies on coal. They examine two scenarios, one in which high income OECD countries remove domestic coal production subsidies and import restrictions at the same time. They find an average decrease of global $\mathrm{CO}_{2}$ emissions of $5 \%$. In the second scenario they additionally assume a removal of coal consumer subsidies and export taxes in Non-OECD countries and find an overall emission reduction of $8 \%$. However, these strong results heavily rely on the authors' "guess-estimates" of the subsidy levels, with subsidy removal increasing production costs by up to $250 \%$.

Fulton et al. (2015) utilize a supply-demand partial equilibrium framework to derive aggregate supply and demand functions and assess the effect of adjusting the supply function by removing subsidies for coal in the U.S. Powder River Basin (PRB) as well as for Australian coal with a horizon from 2014 to 2035. Using a sensitivity analysis, they compute results for different demand elasticities and find that 
an increase of PRB supply costs by 4 USD leads to an annual emissions reduction of 21-55 $\mathrm{MtCO}_{2}$. The authors warn that unilateral removal of subsides again is prone to leakage effects.

\subsection{Current subsidies on coal production in selected countries}

While there are various sources that report fossil fuel subsidy levels for different countries, the quality of available data differs substantially for observed countries. Comparing different sources, I have compiled a data set on steam coal production subsidies for eight major producers of steam coal, namely, USA, China, India, Australia, South Africa, Indonesia, Russia, and Poland (cf. Table 1). Identified subsidy levels range between 0.01 bn USD in Poland and 4.4 bn USD in China, for 20132014. Per unit subsidies range between 0.1 USD/t for exported steam coal in Poland and 3.4 USD/t for steam coal produced in the Powder River Basin. A detailed description of the sources and of the calculation of subsidy levels for each of the analyzed countries can be found in Appendix 0 .

\begin{tabular}{|c|c|c|c|}
\hline Country & $\begin{array}{l}\text { Total subsidies to } \\
\text { coal production in } \\
2013 \text { [bn USD] }\end{array}$ & $\begin{array}{l}\text { Subsidy per unit of } \\
\text { production and by } \\
\text { region [USD/t] }\end{array}$ & Comments \\
\hline USA & 2.1 & $\begin{array}{l}\text { Powder River Basin } 3.4 \\
\text { Appalachia } 1.1 \\
\text { others } 1.0\end{array}$ & $\begin{array}{l}\text { Forgone profits due to preferential tax } \\
\text { treatment account for } 50 \%\end{array}$ \\
\hline China & 4.4 & $\begin{array}{l}\text { Shanxi, Shaanxi, Inner } \\
\text { Mongolia } 1.3 \\
\text { others } 0.9\end{array}$ & $\begin{array}{l}\text { Direct payments and investments, and } \\
\text { the provision of services below market } \\
\text { value account for } 54 \% \text {, and } 39 \% \text {, } \\
\text { respectively. }\end{array}$ \\
\hline India & 0.8 & all 0.9 & Investment by SOE Coal India Limited \\
\hline Australia & 1.0 & $\begin{array}{l}\text { New South Wales } 2.5 \\
\text { Queensland } 2.1 \\
\text { others } 1.8\end{array}$ & $\begin{array}{l}\text { Lax treatment of rehabilitation liabilities } \\
\text { constitutes major subsidy }\end{array}$ \\
\hline $\begin{array}{l}\text { South } \\
\text { Africa }\end{array}$ & 0.04 & $\begin{array}{l}\text { transport to export } \\
\text { terminal } 0.5\end{array}$ & $\begin{array}{l}\text { Rail transport subsidy, below market } \\
\text { value sales to preferential consumers } \\
\text { already disregarded in base case data }\end{array}$ \\
\hline Indonesia & 0.9 & all 1.8 & $\begin{array}{l}\text { Policies targeting to remove subsidies are } \\
\text { not enforced }\end{array}$ \\
\hline Russia & 0.07 & 0.4 & $\begin{array}{l}\text { Extreme divergence between sources on } \\
\text { subsidy levels }\end{array}$ \\
\hline Poland & 0.01 & 0.1 & Free energy supply for mine workers \\
\hline
\end{tabular}

Table 1: Total subsidy in 2013/2014 and subsidy per unit of production and by region for main coal producing countries.

Source: Own compilation based on various sources. See country descriptions in the Appendix for details.

\subsection{Quantitative assessment: production subsidy reform}

Quantitative results are obtained by employing the COALMOD-World model introduced in Mendelevitch et al. (forthcoming) and Holz et al. (2015). The marginal cost intercept is adjusted according to the collected subsidy estimates reported in Table 1 to account for the removed subsidy. In the case of South Africa transportation costs between producer and exporter are adjusted, respectively.

The net effect of steam coal production subsidy removal on global $\mathrm{CO}_{2}$ emissions from steam coal is an emissions reduction of $2.5 \mathrm{GtCO}_{2}$ (82 $\mathrm{MtCO}_{2}$ annually) for the model horizon until 2050. Roughly the same effect can be observed if Australia introduces a steam coal export tax of $18 \mathrm{USD} / \mathrm{t}$ (see 
Richter, Mendelevitch, and Jotzo 2015)or if the U.S. unilaterally decides to introduce a moratorium on new coal mines on federal land (see Section 4 . The effect can be considered insignificant, if compared to the required average annual reduction of $3.6 \mathrm{GtCO}_{2}$, to close the gap between the WEO 2015 NPS and the 450ppm scenario (cf. Mendelevitch et al. forthcoming). Table 2 reports results on producer, exporter, and consumer surplus, as well as total discounted level of removed subsidies. ${ }^{9}$ For the period 2020 to 2050, saved subsidies total 76 bn USD. While for the reformed countries producer surplus is reduced to a smaller extend than consumer surplus ( 24.7 bn USD and 34.3 bn USD, respectively), their net welfare effect is positive and totals $18 \mathrm{bn}$ USD. The net effect for all examined countries is positive, except for India, due to its disadvantages role as a large net importer over the entire model horizon. As the subsidy only affects export coal, consumers in South Africa are not affected by the policy. The policy induces an average price increase of $1 \%$ over the entire model horizon. South African, Russian, and Polish producers overall benefit from the policy as their cost increase is small relative to their competitors from Indonesia, Australia, and USA, therefore they exhibit a positive change in producer surplus.

In general, the removal of producer subsidies does not have a major impact on the steam coal market. Total saved subsidy volume accounts for $1.5 \%$ of total market volume over the model horizon. Though the net welfare effect is positive, it accounts for only $0.4 \%$ of total market volume over the same period.

Table 2: Effect of subsidy removal on producer, exporter, and consumer surplus.

\begin{tabular}{lccccccccc}
\hline \hline $\begin{array}{l}\text { [bn USD 2020-2050, discounted } \\
\text { to 2020] }\end{array}$ & CHN & IND & IDN & USA & AUS & ZAF & RUS & POL & Total \\
\hline Total subsidy & 31.5 & 8.1 & 7.2 & 23.1 & 4.5 & 0.8 & 0.8 & 0.1 & 76 \\
Producer surplus & -12.6 & -2.3 & -4.3 & -6.2 & -2.2 & 0.1 & 0.5 & 0.1 & -24.7 \\
Exporter surplus & 2 & - & 0.4 & -1.9 & 0 & 0.4 & 0 & 0 & 1 \\
Consumer surplus & -15 & -6.3 & -0.5 & -7.1 & -0.5 & 0.0 & -0.8 & -0.1 & -34.3 \\
Net welfare effect & 5.9 & -0.5 & 2.8 & 7.9 & 1.8 & 1.3 & 0.5 & 0.1 & 18 \\
\hline \hline
\end{tabular}

\section{A moratorium on new coal-mines as a supply-side climate policy}

The "No New Coal Mines" initiative was started by the President of Kiribati who urged the leaders of the world to support this call for a moratorium on new and expansion of existing coal mines (Tong 2015). It is supported ,inter alia, by Sir Nicolas Stern (Grantham Research Institute 2015b) and by the Australia Institute (Denniss 2015b), but also the U.S. and China have introduced a temporary moratorium on new coal mines (Warrick and Eilperin 2016; The State Council of the People's Republic of China 2016). In addition to the usually quoted positive effects associated with reducing coal consumption, including environmental and health impacts, the proponents of a moratorium policy argue that it will also avoid stranded assets along the entire coal value chain and additionally reduce consumption through increased prices (Denniss 2015a; Finighan 2016). However, the policy comes

\footnotetext{
${ }^{9}$ All monetary values are discounted to 2020 , the year when the policy is assumed to be introduces. There is no anticipation of the policy in the preceding years, as the variables are fixed to "no policy" values for 2010 and 2015.
} 
with a caveat: Putting a moratorium on new coal mines gives a clear advantage to current incumbents and disadvantages new entrants (Denniss 2015a). In times of low coal prices and overcapacities on the market, the policy can also be understood as a classical industry support instrument. In the shortto medium-term a moratorium on new mines will stabilize prices, and thus generate revenue to current owners of resources and secure jobs and investments in current operations. ${ }^{10}$ At the same time, local economic benefits from new entrants and revenue from lease auctioning and royalties are foregone if a mine moratorium is implemented. Moreover, it potentially increases the carbon budget available to other fossil fuels, namely, to oil and gas.

Literature that quantifies the effect of a moratorium on new coal mines is very sparse. Erickson and Lazarus (2016) examine the effect of phasing-out leases for fossil fuel extraction on governmentowned land from which $40 \%$ of coal production currently originates in the U.S. For coal, their scenario assumes that currently issued licenses where production did not start are revoked and no new licenses are issued. They account for inter- and infra-fuel substitution and find that for coal such a policy could lead to emission reductions of $70 \mathrm{MtCO}_{2} / \mathrm{a}$, already corrected for a rise of $30 \mathrm{MtCO}_{2} / \mathrm{a}$ from an increase in gas-fired electricity production. Finighan (2016) examines whether a global moratorium on coal mines would lead to a remaining coal budget that is consistent which the amount considered as "burnable" by McGlade and Ekins (2015). The latter uses a global energy systems model with a detailed representation of resources and reserves to assess the amount of fossil fuel that needs to remain in the ground to be in accordance with a $2^{\circ} \mathrm{C}$ target. Based on their assumptions on the costs and the availability of fossil reserves, $82-88 \%$ of coal reserves (and at least $96 \%$ of resources) must not be extracted. Finighan (2016) highlights that there is a lack of information on coal reserves in existing mines, which, however, would be required to test a "Mine moratorium" policy against the results obtained by McGlade and Ekins (2015). To overcome this lack, he employs two approaches: the first method uses a limited set of countries to estimate an average ratio of reserves to reserves in active mines and calculates $140 \mathrm{Gt}$ of coal remaining in operating mines. The second method is based on the simplifying assumption that the lifespan of current mining operations is 20 years, and therefore current production levels could be maintained for 20 more years, if no new mines would be opened. Assuming an annual decrease in production of $5 \%$, this method arrives at $126 \mathrm{Gt}$ of coal remaining until 2050. Finighan (2016) finds that based on his estimates a mine moratorium would achieve a limitation of coal supply to volumes that are in line which the "coal budget" of 120 to $180 \mathrm{Gt}$ calculated by McGlade and Ekins (2015) until 2050. However, the analysis has a number of drawbacks:

- it relies on rule-of-thumb estimates of reserves in operating mines rather than a comprehensive data set,

- it does not allow to quantify the effects on market prices, trade patterns, and potential winners and losers of such a policy,

\footnotetext{
${ }^{10}$ E.g., Forsythe (2016) argues that current halt of coal-fired power plant construction and coal mines approval is rather due to economic reasons that to environmental concerns.
} 
- and it does not account for the heterogeneity of coal types and embedded specific $\mathrm{CO}_{2}$ emissions.

The following two subsections address some of the short-comings discussed above. Section 4.1 comprises an attempt to comprehensively collect data on coal reserves in operating mines for the major coal producing countries. Section 4.2.2 provides a quantitative assessment evaluating the effects on trade patterns, prices, $\mathrm{CO}_{2}$ emissions from coal, and welfare effects.

\subsection{Remaining coal reserves in operating mines}

Due to individual assessment methods, prevailing complexity of measurement and measurement errors, as well as a political component, estimates of reserves and resources are hard to obtain and prone to substantial uncertainty. While there exists an international code for fossil fuel energy and mineral reserves and resources classification (UN 2013), it is not broadly used. Rather the code developed by the Joint Ore Reserve Committee (JORC 2012) is more and more commonly applied by companies, also outside its original Australasian scope. Based on various sources, BGR (2015) provides a comprehensive list of resource and reserves estimates for 81 countries. According to BGR $(2015,43)$, hard coal reserves totaled $699 \mathrm{Gt}$ in 2014. A more in-depth, country-by-country analysis is available from the World Energy Council (2013) which reports a similar value of $691 \mathrm{Gt}$ of proved recoverable reserves of anthracite, other bituminous and sub-bituminous coal by end of 2011. Thurber and Morse (2015) and Osborne (2013), both provide a selected number of country case studies providing estimates of recoverable reserves and resources. The NGO "coalswarm" ${ }^{11}$ provides an incomplete list of mining operations in a limited number of countries. Commercial providers like "IntierraRMG"12 or "Mining Atlas"13 advertise to provide a comprehensive data set on operating mines globally, which, however, are not openly accessible. To my best knowledge, there is no comprehensive database that consistently reports remaining coal reserves in operating mines.

In the following, I present a comprehensive data set of coal reserves in operating mines ${ }^{14}$ on a country level. A detailed description of data origins and calculation methods can be found in Appendix 0 . Where available, mine level data was used based on publicly available data, inter alia, company reports, and ministry sources. For some countries, no such data could be acquired. Especially for China, due to a lack of available alternatives, I follow the methodology introduced in Finighan (2016). I apply an average quota of "reserves" to "reserves in operating mines" calculated based on available sources and apply it to reserves in China as reported in BGR (2015).

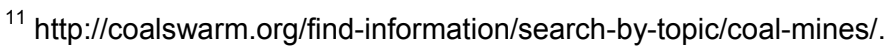

${ }^{12}$ http://www.snl.com/Sectors/metalsmining/Default.aspx.

${ }^{13} \mathrm{https} / / /$ mining-atlas.com/operation/php.

${ }^{14}$ There is no clear-cut definition of coal reserves in operating mines. Where available, I rely on JORC code 111, Proved extractable reserves, reported for individual mine operations. I presume that extraction rights for these quantities are already acquired but I do not investigate the legal aspects in detail. Therefore, these figures might include coal reserves that are currently not developed but already considered a company asset. A further investigation of individual country mining and environmental law would be required to assess in how far such undeveloped reserves could also be retained in the ground without the need to adapt legislation and to cut into the legal rights of the individual companies.
} 
Table 3: Estimates of resources and reserves from literature, and own estimates on reserves in operating mines.

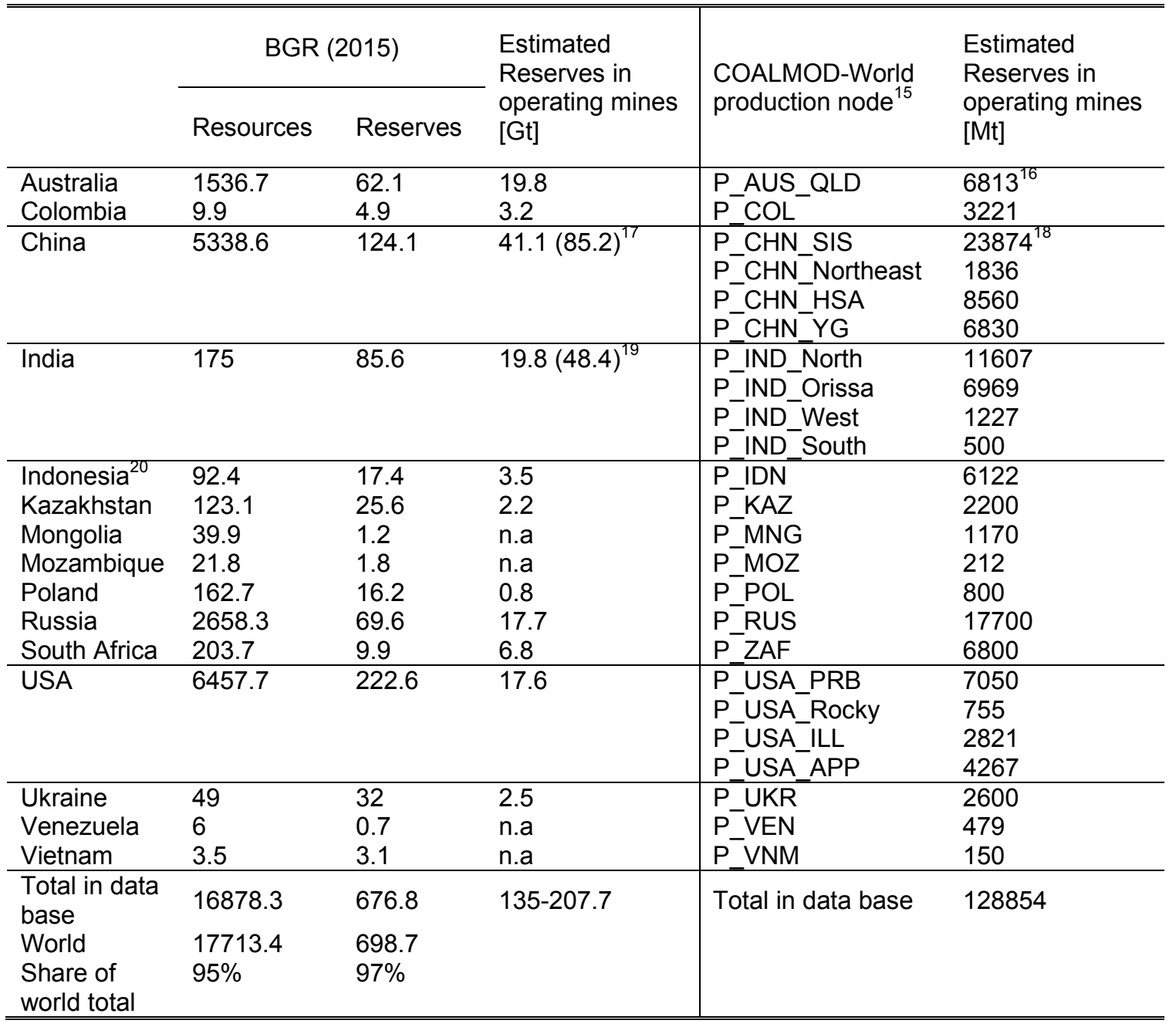

Source: based on various sources as described for each country below.

\footnotetext{
${ }^{15}$ Figures are adjusted and redistributed to coal basins covered by the COALMOD-World database.

${ }^{16}$ Geosience Australia (2014) reports a spit of 7442/11547 between New South Wales and Queensland. I assume this ratio to remain constant. As COALMOD-World only covers international steam coal markets, numbers displayed apply the split between coking coal and steam coal using the current split in production figures with an average share of $59 \%$ for steam coal as reported by the Australian Government (2016) for the period 2009-2013.

17 The numbers are calculated based on the ratio of reserves reported by BGR (2015) to reserve in operating mines directly obtained from literature (for USA, Colombia, Poland, South Africa, Indonesia, and Australia). The number in brackets is based on the highest ratio obtained in South Africa (69\%), while the standard assumption is the average ratio (33\%).

${ }^{18}$ Figures are distributed to the regional level based on the regional split employed in the COALMOD-World data base (see Mendelevitch et al. forthcoming).

19 The figure in brackets assumes that captive mine licenses are reissued while the standard assumption is that they are retired.

${ }^{20}$ As the value of $3.5 \mathrm{Gt}$ represents reserves as of end of 2015 , to account for the model setting starting in 2010 , the consumed amounts for 2010-2015 are added based on data from IEA (2015b; 2012).
} 


\subsection{Quantitative assessment: Mine Moratorium Scenario}

Assuming an unanticipated reduction of available reserves to the levels reported in Section 4.1 in 2020 reduces total production by $42 \%$ (cf. Table 4). This corresponds to an emission reduction of on average $6.9 \mathrm{Gt}$ per year for the period $2020-2050$ or $5.2 \mathrm{Gt}$ per year for $2010-2050$. Annual $\mathrm{CO}_{2}$ emissions from coal in 2040 are $75 \%$ below the level observed in the reference case. The reserve constraint is binding for all steam coal producers, except Ukraine, Russia, and Australia Queensland producers, who can even expand their export compared to the reference case. This is due to the fact that these countries have low domestic consumption and have installed production at large deposits or just recently expanded production as in the case of Australia. Restricted reserves add a scarcity rent of on average 52.1 USD/t (production-weighted) to the price of coal. The policy leads to an average global price increase of $93 \%$ for the period 2020 to 2050 . The global net welfare effect, disregarding any positive effect on climate change mitigation, is a $19 \%$ reduction in welfare, where a relative increase in producer surplus by $70 \%$ is outnumbered by a reduction in consumer surplus by $53 \%$. The reduction in net welfare amounts to $18.4 \%$ of the steam coal market volume in the period 2020 to 2050. The highest reduction in consumer surplus can be observed in China, followed by India and USA. The policy comes with net benefits especially for Russia, Australia, and Colombia who profit from increased prices and reduced supply from competitors, especially from Indonesia. For South Africa there is a balance between positive price effects for exports and negative effects of a price increase on domestic consumption.

With tight reserve constraints, Chinese coal reserves are used up until 2040, while it increasingly relies on imports. Seaborne trade sees an even stronger concentration on China and India, while both domestic supply and imports to other countries is reduced by over $90 \%$. Japan, Korea, Malaysia and Taiwan, are the only countries that have significant imports in 2040, besides China and India. USA consumption is reduced by on average $50 \%$, with all reserves being used up by 2040 . Similarly, South Africa uses up its reserves by 2040 , Indonesia by 2035 , and Poland by 2025 . In total, international trade is reduced by $42 \%$ for the period 2020 to 2040 (as can be seen in Figure 2).

Table 4: Cumulative production in the reference case and in the Mine Moratorium scenario in Gt.

\begin{tabular}{llll|llll}
\hline \hline \multicolumn{3}{c|}{ Cumulative production [Gt] } & & \multicolumn{4}{c}{ Cumulative production [Gt] } \\
\cline { 1 - 3 } Country & Base case & $\begin{array}{l}\text { Mine Morat. } \\
\text { Scenario }\end{array}$ & $\begin{array}{l}\text { Change } \\
\text { in } \%\end{array}$ & Country & Base case & $\begin{array}{l}\text { Mine Morat. } \\
\text { Scenario }\end{array}$ & $\begin{array}{l}\text { Change } \\
\text { in \% }\end{array}$ \\
\hline AUS & 6.4 & 8.8 & 38 & POL & 1.9 & 0.8 & -58 \\
CHN & 89.7 & 41.1 & -54 & RUS & 6.6 & 10.6 & 61 \\
COL & 4.9 & 3.2 & -35 & UKR & 1.5 & 2.1 & 40 \\
IDN & 13.0 & 6.1 & -53 & USA & 32.3 & 14.9 & -54 \\
IND & 30.1 & 20.3 & -33 & VEN & 0.5 & 0.5 & 0 \\
KAZ & 3.5 & 2.2 & -37 & VNM & 0.2 & 0.2 & 0 \\
MNG & 1.2 & 1.2 & 0 & ZAF & 12.0 & 6.8 & -43 \\
MOZ & 0.2 & 0.2 & 0 & Total & 204.0 & 119.0 & -42 \\
\hline \hline
\end{tabular}




\subsubsection{Alternative specification: High estimate of reserves in operating mines}

This scenario assumes that available reserves in China and India are at the high estimate level reported in Table 3, which corresponds to an increase of $208 \%$ and $244 \%$, respectively, compared to the values used in the "Mine Moratorium" scenario. In this scenario, results are in strong contrast to outcomes in the "Mine moratorium" scenario. Total production is only reduced by $18 \%$ compared to the reference case. This corresponds to an emission reduction of on average $2.1 \mathrm{Gt}$ per year for the period 2020-2050 or 2.9 Gt per year for 2010-2050. Moreover, the scenario does not achieve a supply path that is consistent with the $2^{\circ} \mathrm{C}$ target as suggested by the WEO 450ppm scenario (cf. Figure 2). Due to the increased resource base, the reserve constraint is not binding for some regions in China and also for North India and Indian Orissa region.

As in the "Mine Moratorium" scenario, Australia, Russia and Ukraine do not deplete their reserves. Constraint reserves add on average 16.4 USD/t (production-weighted) to the price of coal, compared to $51.4 \mathrm{USD} / \mathrm{t}$ in the "Mine moratorium" scenario. The policy leads to an average global price increase of $33 \%$ for the period 2020 to 2050 . Benefits for exporters, especially Russia and Australia, are $75 \%$ lower than in the "Mine Moratorium" scenario. The net welfare effect, disregarding any positive effect from climate change mitigation, is a $9 \%$ reduction in welfare, where a relative increase in producer surplus of $40 \%$ is outnumbered by a reduction in consumer surplus of $27 \%$. This is less than half of the magnitude observed for the "Mine Moratorium" scenario. The reduction in net welfare amounts to $8.8 \%$ of the market volume of the steam coal in the period 2020 to 2050 . With a reduction of $75 \%$ for the period 2020 to 2040, international trade is reduced twice as strong as in the "Mine Moratorium" scenario, due to more supply available on the domestic markets in China and India.

\subsubsection{Alternative specification: McGlade and Ekins 2015 (M\&E) scenario}

It is worth mentioning that, although both the WEO 450ppm scenario (2015a) and the calculations by McGlade and Ekins (2015), are based on an energy system that is consistent with the $2^{\circ} \mathrm{C}$ target, there is a strong divergence in the role that coal plays in these energy systems. While the former assumes that Carbon Capture, Transport and Storage (CCTS) is readily available, and has a share of $75 \%$ of total coal-fired electricity generation by 2040 , the latter presents two specifications, including one without CCTS. There are two important caveats of the technology: First, CCTS increases coal required to produce the same amount of energy due to reduced efficiency (see Oei, Herold, Mendelevitch (2014) for technical details on CCTS), and second, the technology is no available even at demonstration scale, yet (see section 1). Taking these issues into account, figures on future coal demand provided by the WEO 450ppm scenario likely need to be corrected downwards to be consistent with a $2^{\circ} \mathrm{C}$ target. Therefore, I also calculate coal supply patterns implied by coal reserves considered "burnable" by McGlade and Ekins (2015) in their specification without CCTS in this M\&E scenario.

For the M\&E scenario, I assume the introduction of a restriction of steam coal reserves as reported in Table 7 in the Appendix, from 2020 onwards. For the period 2010-2020 there is no anticipation effect and the consumption is based on reserve data from the COALMOD-World dataset. Compared to the "Mine moratorium" scenario reserves are even more constrained, but also the distribution of reserves 
is different. In the M\&E scenario Poland has higher resource base, whereas reserves in Ukraine and Russia are substantially lower. Lower reserves are also assumed for South Africa, and Australia, while the resource base in Indonesia is almost at reference case levels. Finally, the split of reserves between China and India is different, with a larger share available to China.

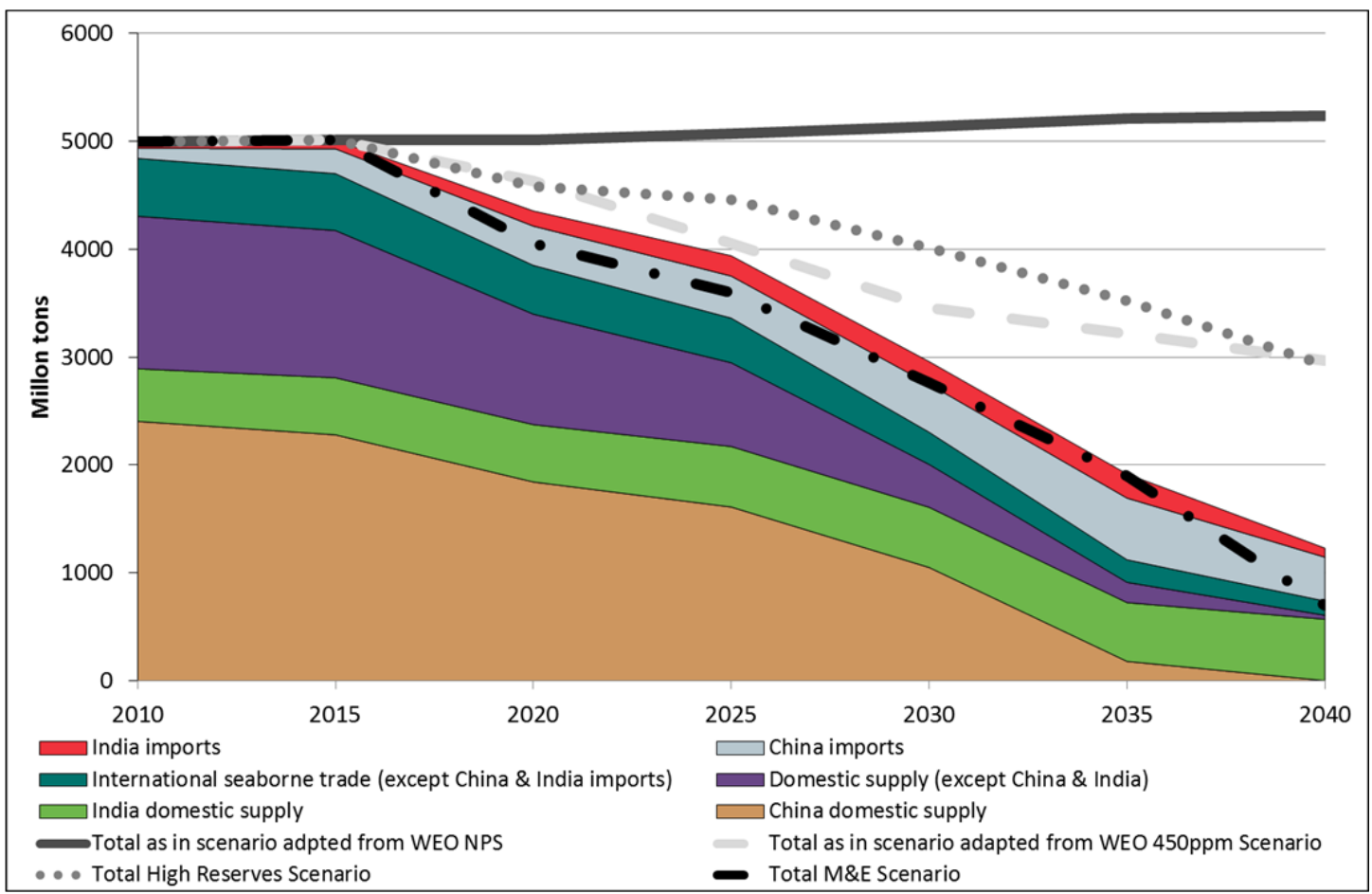

Figure 2: Total supply from imports and domestic production in the "Mine Moratorium" scenario, and total supply from scenarios with alternative specifications (in Mtpa).

Due to similar total reserve base, results are in the same range as for the "Mine Moratorium" scenario. Total production is reduced by $47 \%$ (cf. Table 6 in Appendix A.X) compared to the reference case, which corresponds to an emission reduction of on average $7.8 \mathrm{Gt}$ per year for the period 2020-2050 or $5.8 \mathrm{Gt}$ per year for 2010-2050. The reserve constraint is binding for all steam coal producers, except for Poland. The constraint adds on average 56.4 USD/t (production-weighted) to the price of coal. The policy leads to an average price increase of $102 \%$ for the period 2020 to 2050 . The net welfare effect, disregarding any positive effect from climate change mitigation, is a $21 \%$ reduction in welfare, where a relative increase in producer surplus of $61 \%$ is outnumbered by a reduction in consumer surplus of $23 \%$ and exporter surplus of $51 \%$. The reduction in net welfare amounts to $19.4 \%$ of the market volume of steam coal markets in the period 2020 to 2050. More reserves available in Indonesia are outnumbered by reductions in Russia and Ukraine. Therefore, international trade cannot compensate for additionally tightened reserves in India. Consequently, production levels in 2040 are even below those in the "Mine Moratorium" scenario. International trade is reduced by $53 \%$ compared to the reference case for the period 2020 to 2040. 


\section{Conclusions}

Reducing coal consumption is one of the core means to achieve the $2^{\circ} \mathrm{C}$ target. Observing frustration on the outcomes achieved by demand-side climate policies in the past two decades, supply-side policies represent an alternative approach which can complement demand-side climate change mitigation efforts. In paper I investigate the effect of two supply-side climate policies on consumption, prices, and patterns of trade on the international steam coal market and domestic coal markets.

The first policy follows the suggestions of the G20 (2009) and other influential groups and examines the effects of removing subsidies for steam coal production. The policy comes with a double-dividend, by first removing heavy burdens from public budgets and, second, reducing greenhouse gas emissions. I find subsidy levels ranging from $0.1 \mathrm{USD} / \mathrm{t}$ in Poland to $3.4 \mathrm{USD} / \mathrm{t}$ for U.S. coal from the Powder River Basin. While I find a positive welfare effect of removing these subsidies of in total $18 \mathrm{bn}$ USD for the period 2020 to 2050, the effect on $\mathrm{CO}_{2}$ emissions from coal can be considered insignificant for a global policy. The calculated average annual reduction of $82 \mathrm{MtCO}_{2} / \mathrm{a}$ only makes up for a small fraction of the $3.6 \mathrm{GtCO}_{2} /$ a required to be consistent with the $2^{\circ} \mathrm{C}$ target.

Still, the removal of production subsidies for fossil fuels can work as an effective supply-side climate policy. However, such a reform should not be considered as an isolated measure but as part of an integrated climate policy package. On the contrary, if accompanying policies aimed at internalizing fossil fuel externalities, are not implemented across fuels, a pure subsidy reform can even lead to an increase in domestic coal consumption, like investigated for Indonesia by ADB (2015).

As the definition of subsidies is non-specific on whether a subsidy is for some reason justified or suited to correct for market failure, the figures used in this paper also include measures such as compensation payments for mines shut down in the Chinese "Coal Phase-Out Plan" (cf. Appendix 0). These payments may be well justified as they reduce output in the long-term and provide a transition period to mitigate negative effects on local small scale firms. To provide an integrated cost-benefit analysis for each of the policy interventions interpreted as subsidies is beyond the scope of this paper. The figures presented should rather be interpreted as first attempt to consistently assess the economic and environmental effect of removing coal production subsidies on global coal consumption and trade patterns on the global steam coal market.

The set of subsidies included in this analysis does not include the costs induced by not accounting for externalities caused by the production and consumption of coal which can be understood as a social subsidy. This is common practice by IMF (2015). Estimates of these "social costs of carbon" are difficult to obtain, but are increasingly incorporated into policy and other impact assessment studies. Depending on the discount rate and timing of the emissions EPA reports "social cost of carbon" between $11 \mathrm{USD} / \mathrm{tCO}_{2}$ and $95 \mathrm{USD} / \mathrm{tCO}_{2}$ (EPA 2015b). Including such additional costs would have a significant effect on coal consumption, but also on trade.

The second policy that is investigated in this paper is a moratorium on new and expansion of existing mines as suggested by Tong (2015), President of the Republic of Kiribati, but also other scholars. The

policy again comes with a double-dividend: First, it achieves emission reductions by conserving reserves, and second, compensating current resource owners through increased scarcity rents and 
therefore market prices. Due to a lack of consistent data on reserves in operating mines, I compile my own data set based on publicly available data. Total reserves in these mines are estimated at 137.3$210 \mathrm{Gt}$, depending on assumed reserves in India and China.

While the high estimate of remaining reserves fails to achieve a consumption pattern in line with the WEO 450ppm scenario, the "Mine Moratorium" scenario, assuming the lower estimates exceed required reductions. The supply path in this scenario is, however, in line with McGlade and Ekins' (2015) calculations on "unburnable" reserves coal. These are required to stay in the ground in order to achieve the $2^{\circ} \mathrm{C}$ target, without relying on CCTS. In the "Mine Moratorium" scenario, prices increase by on average $93 \%$, while total production is reduced by $42 \%$. Not taking into account the positive effects of reduced emissions of $\mathrm{CO}_{2}$ and other local pollutants as well other local externalities, the positive effect to producers is outnumbered by a decrease in consumer welfare, leading to a net welfare reduction of $19 \%$.

While, on the long run, a permanent mine moratorium can be a significant contribution to climate change mitigation, the policy comes with a serious caveat: In the short- to medium-term, it is particularly beneficial for current incumbents and disadvantages new entrants. Therefore, such a policy should not be considered to be introduced in isolation. Otherwise, there is a risk that it will be deemed a temporal industry support policy that protects current incumbents without any long-term effect on reducing $\mathrm{CO}_{2}$ emissions.

Both examined policies are very much suited to be applied in a broader scope, covering not only coal but eventually all fossil fuels. The effect of the timing of the introduction and a potential expansion of the policies across fossil fuels should be further investigated. It is likely to govern in how far inter-fuel competition can be used to temporally align incentive and create favorable conditions to introduce such policies.

\section{Acknowledgements}

I would like to thank Tim Scherwath for providing excellent research assistance. Moreover, I thank Christian von Hirschhausen, Franziska Holz, Pao-Yu Oei and Fabian Stöckl, as well as the participants of the DIW Brown Bag Seminar for helpful discussions and feedback. Special thanks go to Fabian Stöckl, Pao-Yu Oei and Tim Scherwath for reviewing the manuscript. All remaining errors are with the author. 


\section{References}

ADB. 2015. "Fossil Fuel Subsidies in Indonesia; Trends, Impacts, and Reforms." Mandaluyong City, Philippines: Asian Development Bank. http://lib.myilibrary.com?id=902326.

Anderson, Kym, and Warwick J. McKibbin. 2000. "Reducing Coal Subsidies and Trade Barriers: Their Contribution to Greenhouse Gas Abatement." Environment and Development Economics, no. 4(Oktober): 457-481.

APEC. 2010. "2010 Leaders' Declaration.” Asia-Pacific Economic Cooperation. November 13. http://www.apec.org/Meeting-Papers/Leaders-Declarations/2010/2010_aelm.aspx.

Arze del Granado, Francisco Javier, David Coady, and Robert Gillingham. 2012. "The Unequal Benefits of Fuel Subsidies: A Review of Evidence for Developing Countries." World Development 40 (11): 2234-48. doi:10.1016/j.worlddev.2012.05.005.

Australian Government. 2016. "Resources: Coal." Australian Government Department of Industry, Innovation Adn Science. http://www.industry.gov.au/resource/Mining/AustralianMineralCommodities/Pages/Coal.aspx.

Bárány, Ambrus, and Dalia Grigonytè. 2015. "Measuring Fossil Fuel Subsidies." Brussels, Belgium: European Commission, Directorate-General for Economic and Financial Affairs. http://bookshop.europa.eu/uri?target=EUB:NOTICE:KCAY15040:EN:HTML.

Bast, Elizabeth, Alex Doukas, Sam Pickard, Laurie van der Burg, and Shelagh Whitley. 2015. "Empty Promises: G20 Subsidies to Oil, Gas and Coal Production." Oversea Development Institute (ODI) and Oil Change International (OCl). http://www.qualenergia.it/sites/default/files/articolodoc/Fossil_subsidies_full_ODI.pdf.

Bauer, Nico, Ioanna Mouratiadou, Gunnar Luderer, Lavinia Baumstark, Robert J. Brecha, Ottmar Edenhofer, and Elmar Kriegler. 2013. "Global Fossil Energy Markets and Climate Change Mitigation - an Analysis with REMIND." Climatic Change, October, 1-14. doi:10.1007/s10584013-0901-6.

Beaton, Christopher, Ivetta Gerasimchuk, Tara Laan, Kerryn Lang, Damon Vis-Dunbar, and Peter Wooders. 2013. "A Guidebook to Fossil-Fuel Subsidy Reform for Policy Makers in Southeast Asia." Winnipeg, Canada: International Institute for Sustainable Development.

BGR. 2015. "Energy Study 2015: Reserves, Resources and Availability of Energy Resources." 19. Hannover, Germany: The Federal Institute for Geosciences and Natural Resources (BGR) on behalf of the German Mineral Resources Agency (DERA). http://www.bgr.bund.de/EN/Themen/Energie/Downloads/energiestudie_2013_en.pdf;jsessioni d=B54D487C8482BDF37835843002A0A66D.1_cid331?_blob=publicationFile\&v=2.

Boren, Zachary Davies. 2016. "China Stops Building New Coal-Fired Power Plants." Energydesk. March 24. http://energydesk.greenpeace.org/2016/03/24/china-crackdown-new-coal-powerplants/.

Britt, A.F., D. Summerfield, A. Whitaker, P. Kay, D.C. Champion, D. Huston, A.B. Senior, et al. 2015. "Australia's Identified Mineral Resources 2015." Australia's Identified Mineral Resources. Geoscience Australia. http://www.ga.gov.au/metadata-gateway/metadata/record/87839/.

Burniaux, Jean-Marc, and Jean Chateau. 2014. "Greenhouse Gases Mitigation Potential and Economic Efficiency of Phasing-out Fossil Fuel Subsidies." International Economics 140 (December): 71-88. doi:10.1016/j.inteco.2014.05.002.

Clements, Benedict J., David Coady, Stefania Fabrizio, Sanjeev Gupta, Trevor Alleyne, and Carlo Sdralevich, eds. 2013. Energy Subsidy Reform: Lessons and Implications. Washington, D.C: International Monetary Fund.

cmpdi. 2014. "UNFC (2004) Classification of Coal Resources of CIL Blocks as on 01.04.2013." Ranchi, India: Central Mine Planning and Design Institute Limited.

Coady, David, lan Parry, Louis Sears, and Baoping Shang. 2015. "How Large Are Global Energy Subsidies?" IMF Working Paper WP/15/105. Washington, DC, USA: International Monetary Fund, Fiscal Affairs Department. 
Coal Controller's Organisation. 2015. "Coal Directory of India 2013 - 2014 Coal Statistics." Kolkata, India: Government of India, Ministry of Coal, Coal Controller's Organisation. http://coal.nic.in/sites/upload_files/coal/files/coalupload/coaldir13-14.pdf.

Collier, Paul, and Anthony J. Venables. 2014. "Closing Coal: Economic and Moral Incentives." Oxford Review of Economic Policy 30 (3): 492-512. doi:10.1093/oxrep/gru024.

Collins, Kim, and Roman Mendelevitch. 2015. "Leaving Coal Unburned: Options for Demand-Side and Supply-Side Policies.” 87. DIW Roundup. Berlin, Germany: German Institute for Economic Research

(DIW

Berlin) http://www.diw.de/documents/publikationen/73/diw_01.c.526889.de/diw_roundup_91_en.pdf.

Dansie, Grant, Marc Lanteigne, and Indra Overland. 2010. "Reducing Energy Subsidies in China, India and Russia: Dilemmas for Decision Makers.” Sustainability 2 (2): 475-93. doi:10.3390/su2020475.

Dartanto, Teguh. 2013. "Reducing Fuel Subsidies and the Implication on Fiscal Balance and Poverty in Indonesia: A Simulation Analysis." Energy Policy 58 (July): 117-34. doi:10.1016/j.enpol.2013.02.040.

Denjean, Benjamin, Ivetta Gerasimchuk, Ken Bossong, Sam Pickard, and Shelagh Whitley. 2015. "G20 Subsidies to Oil, Gas and Coal Production: China." Background Paper for the Report Empty Promises: G20 Subsidies to Oil, Gas and Coal Production. Oil Change International $(\mathrm{OCl})$ and the Overseas Development Institute (ODI). https://www.odi.org/sites/odi.org.uk/files/odi-assets/publications-opinion-files/9985. pdf.

Denniss, Richard. 2015a. "When You're in a Hole - Stop Digging! The Economic Case for a Moratorium on New Coal Mines." Discussion Paper. The Australian Institute. http://www.tai.org.au/sites/defualt/files/Denniss\%202015\%20-

\%20When\%20you\%20are\%20in\%20a\%20hole\%20stop\%20digging_0.pdf.

2015b. "Moratorium on Coal Mines Makes Sense for All." Australian Financial Review. November 3. http://www.afr.com/opinion/moratorium-on-coal-mines-makes-sense-for-all20151102-gkojop.

Doukas, Alex, and Shelagh Whitley. 2015. "G20 Subsidies to Oil, Gas and Coal Production: United States." Background Paper for the Report Empty Promises: G20 Subsidies to Oil, Gas and Coal Production. Oil Change International $(\mathrm{OCl})$ and the Overseas Development Institute (ODI). https://www.odi.org/publications/10086-g20-subsidies-oil-gas-coal-production-unitedstates.

DTEK. 2014. "DTEK 2014 Integrated Report - Financial and Non-Financial Performance."

Durand-Lasserve, Olivier, Lorenza Campagnolo, Jean Chateau, and Rob Dellink. 2015. "Modelling of Distributional Impacts of Energy Subsidy Reforms: An Illustration with Indonesia." OECD Environment Working Papers 86. Paris, France: OECD Publishing. http://www.oecdilibrary.org/environment/modelling-of-distributional-impacts-of-energy-subsidyreforms_5js4k0scrqq5-en.

Eberhard, Anton. 2015. "Market, Investment, and Policy Challenges for South African Coal." In The Global Coal Market: Supplying the Major Fuel for Emerging Economies, edited by Mark C. Thurber and Richard K. Morse. Cambridge University Press.

Ecofys. 2014. "Subsidies and Costs of EU Energy." Final Report. Project number: DESNL14583. By Order of European Commission. London, UK: Ecofys.

EIA. 2015a. "Direct Federal Financial Interventions and Subsidies in Energy in Fiscal Year 2013." Independent Statistics \& Analysis. Washington DC, USA: US Energy Information Administration, US Department of Energy.

_ 2015b. "Analysis of the Impacts of the Clean Power Plan." Washington, D.C., USA: U.S. Energy Information Administration. https://www.eia.gov/analysis/requests/powerplants/cleanplan/pdf/powerplant.pdf.

2016. “Annual Coal Report 2014.” Independent Statistics \& Analysis. Washington, D.C., USA: Department of Energy, U.S. Energy Information Administration. 
EPA. 2015a. "Coal Mine Methane Country Profiles - Chapter 8: Colombia." Washington, D.C., USA: Environmental $\quad$ Protection http://www.globalmethane.org/documents/Toolsres_coal_overview_ch8.pdf.

Agency.

2015b. "EPA Fact Sheet: Social Costs of Carbon." Washington, D.C., USA: Environmental Protection Agency. https://www3.epa.gov/climatechange/Downloads/EPAactivities/social-costcarbon.pdf.

Erickson, Peter, and Michael Lazarus. 2016. "How Would Phasing out U.S. Federal Leases for Fossil Fuel Extraction Affect $\mathrm{CO} 2$ Emissions and $2^{\circ} \mathrm{C}$ Goals?" https://www.seiinternational.org/publications?pid=2937.

Felder, Stefan, and Thomas F. Rutherford. 1993. "Unilateral CO2 Reductions and Carbon Leakage: The Consequences of International Trade in Oil and Basic Materials." Journal of Environmental Economics and Management 25 (2): 162-76. doi:10.1006/jeem.1993.1040.

Fernandes, Ashish, and Tom Sanzillo. 2013. "Coal India Running on Empty? CIL Misleading Investors, Extractable Reserves Could Be Exhausted in 17 Years." India: Greenpeace India. http://www.greenpeace.org/india/Global/india/report/2013/Coal-India-Running-on-Empty.pdf.

Finighan, Reuben. 2016. "The Case for a Coal Mine Moratorium: Reserves within Existing Mines versus the Carbon Budget." Briefing Paper. Melbourne, Australia: University of Melbourne.

Forsythe, Michael. 2016. "China Curbs Plans for More Coal-Fired Power Plants." The New York Times, April 25. http://www.nytimes.com/2016/04/26/business/energy-environment/chinacoal.html.

Fulton, M., T. Buckley, D. Koplow, L. Sussams, and A. Grant. 2015. "A Framework for Assessing Thermal Coal Production Subsidies." London, UK: Energy Transition Advisors, IEEFA, Earth Track, Carbon Tracker Initiative. http://www.carbontracker.org/wpcontent/uploads/2015/09/Thermal-Coal-Prod-Subsidies-final-12-9.pdf.

Fulton, M., P. Spedding, R. Schuwerk, and L. Sussams. 2015. "The Fossil Fuel Transition Blue Print." Energy Transition Advisors and Carbon Tracker Initiative.

G20. 2009. "Leaders' Statement the Pittsburgh Summit." G20. http://www.g20.org/English/Documents/PastPresidency/201512/t20151225_1724.html.

Gandhi, Raina, Christopher R. Knittel, Paula Pedro, and Catherine Wolfram. 2016. "Running Randomized Field Experiments for Energy Efficiency Programs: A Practitioner's Guide." Economics of Energy \& Environmental Policy 5 (2). doi:10.5547/2160-5890.5.2.rgan.

Garg, Vibhuti, and Ken Bossong. 2015. "G20 Subsidies to Oil, Gas and Coal Production: India." Background Paper for the Report Empty Promises: G20 Subsidies to Oil, Gas and Coal Production. Oil Change International $(\mathrm{OCl})$ and the Overseas Development Institute (ODI). https://www.odi.org/sites/odi.org.uk/files/odi-assets/publications-opinion-files/9959.pdf.

Garg, Vibhuti, and Lucy Kitson. 2015. "G20 Subsidies to Oil, Gas and Coal Production: South Africa." Background Paper for the Report Empty Promises: G20 Subsidies to Oil, Gas and Coal Production. Oil Change International $(\mathrm{OCl})$ and the Overseas Development Institute (ODI). https://www.odi.org/sites/odi.org.uk/files/odi-assets/publications-opinion-files/9982.pdf.

Gatot, Bambang, and Pandu Sjahrir. 2015. "Government of Indonesia Postpones the Coal Royalty Hike." Indonesia Investments. July 23. http://www.indonesia-investments.com/news/todaysheadlines/government-of-indonesia-postpones-the-coal-royalty-hike/item5776.

Geosience Australia. 2014. "Black Coal." Australian Government Geosience Australia. May 29. http://www.ga.gov.au/data-pubs/data-and-publications-search/publications/aimr/black-coal.

Gerlagh, Reyer. 2011. “Too Much Oil.” CESifo Economic Studies 57 (1): 79-102.

Glencore. 2016. "Glencore Resources \& Reserves as at 31. December 2015." Glencore. http://www.glencore.com/assets/investors/doc/reports_and_results/2015/GLEN-2015Resources-Reserves-Report.pdf.

Grantham Research Institute. 2015a. "The Global Climate Legislation Database | Grantham Research Institute on Climate Change and the Environment." The Global Climate Legislation Database. http://www.Ise.ac.uk/GranthamInstitute/legislation/the-global-climate-legislation-database/. 
2015b. "Nicholas Stern Welcomes Initiative on Coal Mines by Anote Tong, President of the Republic of Kiribati | Grantham Research Institute on Climate Change and the Environment." August 13. http://www.Ise.ac.uk/GranthamInstitute/news/nicholas-stern-welcomes-initiativeon-coal-mines-by-anote-tong-president-of-the-republic-of-kiribati/.

GSI. 2011. "The Friends of Fossil Fuel Subsidy Reform: Supporting the G-20 and APEC Commitments | Global Subsidies Initiative." Global Subsidies Initiative. February 7. http://www.iisd.org/gsi/news/friends-fossil-fuel-subsidy-reform-supporting-g-20-and-apeccommitments.

Haftendorn, Clemens, Claudia Kemfert, and Franziska Holz. 2012. "What about Coal? Interactions between Climate Policies and the Global Steam Coal Market until 2030." Energy Policy 48: 274-83. doi:doi:10.1016/j.enpol.2012.05.032.

Hahn, Robert, and Robert Metcalfe. 2016. "The Impact of Behavioral Science Experiments on Energy Policy." Economics of Energy \& Environmental Policy 5 (2). doi:10.5547/2160-5890.5.2.rhah.

Harstad, Bård. 2012. "Buy Coal! A Case for Supply-Side Environmental Policy." Journal of Political Economy 120 (1): 77-115. doi:10.1086/665405.

Hirschhausen, Christian von, Johannes Herold, and Pao-Yu Oei. 2012. "How a 'Low Carbon' Innovation Can Fail -Tales from a 'Lost Decade' for Carbon Capture, Transport, and Sequestration (CCTS)." Economics of Energy \& Environmental Policy 1 (2): 115-23. doi:10.5547/2160-5890.1.2.8.

Hoel, Michael. 2012. "Carbon Taxes and the Green Paradox." In Climate Change and Common SenseEssays in Honour of Tom Schelling, edited by Robert W. Hahn and Alistair Ulph. Oxford University

Press. http://www.oxfordscholarship.com/view/10.1093/acprof:oso/9780199692873.001.0001/acprof9780199692873.

- 2013. "Supply Side Climate Policy and the Green Paradox." http://papers.ssrn.com/sol3/papers.cfm?abstract_id=2214897.

Holz, F., C. Haftendorn, R. Mendelevitch, C. v. Hirschhausen, R.K. Morse, and M. C. Thurber. 2015. "The COALMOD-World Model: Coal Markets until 2030." In The Global Coal Market Supplying the Major Fuel for Emerging Economies. Cambridge, UK: Cambridge University Press.

Houde, Sébastien, and Anna C. Spurlock. 2016. "Minimum Energy Efficiency Standards for Appliances: Old and New Economic Rationales." Economics of Energy \& Environmental Policy 5 (2). doi:10.5547/2160-5890.5.2.shou.

IEA. 2012. Coal Information 2012. Coal Information. OECD Publishing. http://www.oecdilibrary.org/energy/coal-information-2012_coal-2012-en.

2015a. World Energy Outlook 2015. World Energy Outlook. Paris, France: International Energy Agency, OECD hublishing. http://www.oecdilibrary.org/docserver/download/6115271e.pdf?expires=1448556316\&id=id\&accname=ocid19 5153\&checksum=B307C9BC7DFBD042C599EF4D6BE236CF.

2015b. Coal Information 2015. Coal Information. IEA. http://www.oecd-ilibrary.org/energy/coalinformation-2015_coal-2015-en.

2016. "IEA Energy Subsidies Database." International Energy Agency, World Energy Outlook. http://www.worldenergyoutlook.org/media/weowebsite/2015/Subsidies20122014.xlsx.

IMF. 2015. "Counting the Cost of Energy Subsidies." International Monetary Fund. 17. http://www.imf.org/external/np/fad/subsidies/data/codata.xlsx.

JORC. 2012. "Australasian Code for Reporting of Exploration Results, Mineral Resources and Ore Reserves - 2012 Edition." Carlton South, Australia: The Joint Ore Reserves Committee of The Australasian Institute of Mining and Metallurgy, Australian Institute of Geoscientists and Minerals Council of Australia.

Kannan, Deepak, Arusha Das, and Mia Corazon Aureus. 2015. "Indonesia Plans New Tax on Thermal Coal Exports from August 8." Coal I Platts News Article \& Story. July 6. http://www.platts.com/latest-news/coal/singapore/indonesia-plans-new-tax-on-thermal-coalexports-27577871. 
Kojima, Masami, and Doug Koplow. 2015. "Fossil Fuel Subsidies: Approaches and Valuation." Working Paper. World Bank Group, Washington, DC. https://openknowledge.worldbank.org/handle/10986/21659.

Kolstad, Charles D., Kevin Urama, John Broome, Annegrete Bruvoll, M. Cariño-Olvera, Don Fullerton, Christian Gollier, et al. 2014. "Social, Economic and Ethical Concepts and Methods." In Climate Change 2014: Mitigation of Climate Change, 173-248. Cambridge, United Kingdom and New York, NY, USA: Cambridge University Press. http://lup.lub.lu.se/record/5104578.

Koplow, D. 2015. "Subsidies to Energy Industries." In Reference Module in Earth Systems and Environmental Sciences. Elsevier. http://www.sciencedirect.com/science/article/pii/B9780124095489092691.

Kossoy, Alexandre, Grzegorz Peszko, Klaus Oppermann, Nicolai Prytz, Noemie Klein, Kornelis Blok, Long Khanh Lam, Lindee Wong, and Bram Borkent. 2015. "State and Trends of Carbon Pricing 2015." 99533. World Bank. http://documents.worldbank.org/curated/en/2015/09/25053834/state-trends-carbon-pricing2015.

Lazarus, Michael, Peter Erickson, and Kevin Tempest. 2015. "Supply-Side Climate Policy: The Road Less Taken," Stockholm Environment Institute, Working Paper, , no. SEI-WP-2015-13 (October): 1-24.

Lin, Boqiang, and Xiaoling Ouyang. 2014. "A Revisit of Fossil-Fuel Subsidies in China: Challenges and Opportunities for Energy Price Reform." Energy Conversion and Management 82 (June): 12434. doi:10.1016/j.enconman.2014.03.030.

Lontoh, Lucky, and Christopher Beaton. 2015. "G20 Subsidies to Oil, Gas and Coal Production: Indonesia." Background Paper for the Report Empty Promises: G20 Subsidies to Oil, Gas and Coal Production. Oil Change International $(\mathrm{OCl})$ and the Overseas Development Institute (ODI). https://www.odi.org/sites/odi.org.uk/files/odi-assets/publications-opinion-files/9964.pdf.

Makhijani, Shakuntala, and Alex Doukas. 2015. "G20 Subsidies to Oil, Gas and Coal Production: Australia." Background Paper for the Report Empty Promises: G20 Subsidies to Oil, Gas and Coal Production. Oil Change International $(\mathrm{OCl})$ and the Overseas Development Institute (ODI). https://www.odi.org/publications/10071-g20-subsidies-oil-gas-coal-production-australia.

Martin, Aran. 2014. "Commodity Exports and Transboundary Atmospheric Impacts: Regulating Coal in an Era of Climate Change." Environmental Politics 23 (4): 590-609. doi:10.1080/09644016.2014.891788.

Martin, Pamela L. 2014. "Ecuador's Yasuní-ITT Initiative: Why Did It Fail?'." International Development Policy| Revue Internationale de Politique de Développement 6: 2014.

McGlade, Christophe, and Paul Ekins. 2015. "The Geographical Distribution of Fossil Fuels Unused When Limiting Global Warming to $2{ }^{\circ} \mathrm{C}$." Nature 517 (7533): 187-90. doi:10.1038/nature14016.

Mendelevitch, Roman, Franziska Holz, Christian von Hirschhausen, and Clemens Haftendorn. forthcoming. "DIW Berlin: A Model of the International Steam Coal Market (COALMODWorld)." DIW Data Documentation 85. Berlin: DIW Berlin.

Merrill, Laura. 2014. "Fossil-Fuel Subsidy Reform - Mitigating Emissions through Getting the Price Right." COP 20 Workshop presented at the Global Subsidies Initiative, International Institute for Sustainable Development, Lima, Peru, December 5.

Merrill, Laura, Melissa Harris, Liesbeth Casier, and Andrea Bassi. 2015. "Fossil-Fuel Subsidies and Climate Change." Nordic Council of Ministers. http://urn.kb.se/resolve?urn=urn:nbn:se:norden:org:diva-3744.

NBSC. 2015. "Statistical Communiqué of the People's Republic of China on the 2014 National Economic and Social Development." February. http://www.stats.gov.cn/english/PressRelease/201502/t20150228_687439.html.

—. 2016. "China Statistical Yearbook-2014." National Bureau of Statistics China. http://www.stats.gov.cn/tjsj/ndsj/2014/indexee.htm.

NSW Department of Industry. 2015. "Thermal Coal: Opportunities in New South Wales, Australia." NSW Department of Industry, Division of Resources \& Energy. 
http://www.resourcesandenergy.nsw.gov.au/_data/assets/pdf_file/0008/581606/thermalcoal.pdf.

OCl. 2015. "Indonesia: Public Finance/Subsidies for Coal." Oil Change International. http://priceofoil.org/content/uploads/2014/06/OCI-Indonesia-Coal-Subsidies-Summary-

February-2014.pdf.

ODI. 2015a. "G20 Subsidies to Oil Gas and Coal Production: China Data Sheet." ODI Shaping Policy for Development. November 2. https://www.odi.org/sites/odi.org.uk/files/odiassets/publications-opinion-files/9987.xlsx.

2015b. "G20 Subsidies to Oil Gas and Coal Production: India Data Sheet." ODI Shaping Policy for Development. November 11. https://www.odi.org/sites/odi.org.uk/files/odiassets/publications-opinion-files/9960.xlsx.

2015c. "G20 Subsidies to Oil Gas and Coal Production: United States Data Sheet." ODI Shaping Policy for Development. November 11. https://www.odi.org/sites/odi.org.uk/files/odiassets/publications-opinion-files/9980.xlsx.

OECD. 2013. "Climate and Carbon: Aligning Prices and Policies." OECD Environment Policy Paper. Paris, France. http://www.oecd-ilibrary.org/environment-and-sustainable-development/climateand-carbon_5k3z11hjg6r7-en.

2015a. "Fossil Fuel Support." Inventory of Estimates Budgetary Support and Tax Expenditures for Fossil Fuels 2015. September. http://www.oecd.org/site/tadffss/.

2015b. OECD Companion to the Inventory of Support Measures for Fossil Fuels 2015. OECD Publishing. http://www.oecd-ilibrary.org/energy/oecd-companion-to-the-inventory-of-supportmeasures-for-fossil-fuels-2015_9789264239616-en.

OECD/IEA. 2016. "Glossary." International Energy Agency, Secure, Sustainable, Together. http://www.iea.org/aboutus/glossary/\#tabs-2.

Oei, Pao-Yu, Johannes Herold, and Roman Mendelevitch. 2014. "Modeling a Carbon Capture, Transport, and Storage Infrastructure for Europe." Environmental Modeling \& Assessment 19 (May): 515-31. doi:10.1007/s10666-014-9409-3.

Oei, Pao-Yu, Claudia Kemfert, Felix Reitz, and Christian von Hirschhausen. 2014. "Coal Power Endangers Climate Targets: Calls for Urgent Action." 8. Economic Bulletin. Berlin, Germany: German Institute for Economic Research. IVAFSI.tuberlin.delunits|Fak_VIIIwiplsharelliteraturIDIW_2014-economic_bulletin_08-5_wb_2614_engl.pdf.

Ogarenko, luliia, Ken Bossong, Ivetta Gerasimchuk, and Sam Pickard. 2015. "G20 Subsidies to Oil, Gas and Coal Production: Russia." Oil Change International (OCl) and the Overseas Development Institute (ODI). https://www.odi.org/sites/odi.org.uk/files/odi-assets/publicationsopinion-files/9969.pdf.

Osborne, D., ed. 2013. The Coal Handbook: Towards Cleaner Production. Volume 2. Woodhead Publishing Series in Energy, no. 51. Philadelphia, USA: Woodhead Pub.

Perman, Roger, Yue Ma, Michael Common, David Maddison, and James Mcgilvray. 2012. Natural Resource and Environmental Economics. 4 edition. Harlow, Essex; New York: Prentice Hall.

PwC. 2015. "Mining in Indonesia 2015." Jakarta, Indonesia: PricewaterhouseCoopers International Limited, Indonesia Office.

Queensland Government. 2016. "Production of Saleable Coal by Individual Mines." Coal Industry Review Statistical Tables - Data | Queensland Government. May 18. https://data.qld.gov.au/dataset/coal-industry-review-statistical-tables/resource/1b7fb643-c88042bf-940b-fc3c582d239d.

Rajagopal, Krishnadas. 2014. "Supreme Court Quashes Allocation of 214 Coal Blocks." The Hindu, September 24. http://www.thehindu.com/news/national/supreme-court-quashes-allocation-ofall-but-four-of-218-coal-blocks/article6441855.ece.

Reiner, David M. 2016. "Learning through a Portfolio of Carbon Capture and Storage Demonstration Projects." Nature Energy 1 (1): 15011. doi:10.1038/nenergy.2015.11. 
Richter, Philipp M. 2015. "Trade and Climate Policies: The Role of Market Structure, Strategic Behaviour, and the Supply Side of Carbon." Berlin, Germany: Technische Universität Berlin. https://opus4.kobv.de/opus4-tuberlin/files/6914/richter_philipp.pdf.

Richter, Philipp M., Roman Mendelevitch, and Frank Jotzo. 2015. "Market Power Rents and Climate Change Mitigation: A Rationale for Coal Taxes?" DIW Berlin, Discussion Paper 1471 ID 2598402. Berlin, Germany: German Institute for Economic Research (DIW Berlin). http://www.diw.de/sixcms/detail.php?id=diw_01.c.502680.de.

Rosenow, Jan, Cor Leguijt, Zsuzsanna Pato, Nick Eyre, and Tina Fawcet. 2016. "An Ex-Ante Evaluation of the EU Energy Efficiency Directive - Article 7." Economics of Energy \& Environmental Policy 5 (2). doi:10.5547/2160-5890.5.2.jros.

SACRM. 2011. "Overview of the South African Coal Value Chain - Prepared as a Basis for the Development of the South African Coal Roadmap." South African Coal Roadmap. http://www.fossilfuel.co.za/initiatives/2013/SACRM-Value-Chain-Overview.pdf.

Sanzillo, Tom. 2015. "Indonesia's Coal-Trafficking Epidemic Requires an Impartial Inquiry." Institute for Energy Economics \& Financial Analysis. June 15. http://ieefa.org/indonesias-coal-traffickingepidemic-requires-an-impartial-inquiry/.

Schwanitz, Valeria Jana, Franziska Piontek, Christoph Bertram, and Gunnar Luderer. 2014. "LongTerm Climate Policy Implications of Phasing out Fossil Fuel Subsidies." Energy Policy 67 (April): 882-94. doi:10.1016/j.enpol.2013.12.015.

Sinn, Hans-Werner. 2008. "Public Policies against Global Warming: A Supply Side Approach." International Tax and Public Finance 15 (4): 360-94. doi:10.1007/s10797-008-9082-z.

2015. "Introductory Comment - The Green Paradox: A Supply-Side View of the Climate Problem." Review of Environmental Economics and Policy 9 (2): 239-45. doi:10.1093/reep/rev011.

Sobczyk, E., and P. Saluga. 2013. "Coal Resource Base in Poland from the Perspective of Using the JORC Code" 23rd World Mining Congress 2013 Proceedings. doi:10.13140/2.1.5119.8724.

SUEK. 2011. "SUEK Annual Report 2011." Open Joint Stock Company Siberian Coal Energy Company.

Tazazanov, Igor. 2012. "Analytical Review Russian Coal Industry." Ugol Magazine, no. Special Issue: 3-13.

The State Council of the People's Republic of China. 2016. "Coal Capacity Guideline Issued." The State Council of the People's Republic of China. February 5. http://english.gov.cn/policies/latest_releases/2016/02/05/content_281475284701738.htm.

Thurber, Mark C., and Richard K. Morse. 2015. The Global Coal Market: Supplying the Major Fuel for Emerging Economies. Cambridge University Press.

Tong, Anote. 2015. "Moratorium on New and Extension of Existing Coal Mines."

UN. 2013. "United Nations Framework Classification for Fossil Energy and Mineral Reserves and Resources 2009 Incorporating Specifications for Its Application (ECE ENERGY SERIES No. 42." New York and Geneva: The United Nations Economic Commission for Europe.

2015. "Transforming Our World: 2030 Agenda for Sustainable Development." A/RES/70/1. United Nations.

United Nations Secretary-General's High-Level Panel on Global Sustainability. 2012. "Resilient People, Resilient Planet: A Future Worth Choosing, Overview." New York, USA: United Nations. uscib.org/docs/GSPReportOverview_A4\%20size.pdf.

Warrick, Joby, and Juliet Eilperin. 2016. "Obama Announces Moratorium on New Federal Coal Leases." The Washington Post. January 15.

World Bank. 1997. "Five Years after Rio: Innovations in Environmental Policy." Environmentally \& Socially Sustainable Development Work in Progress $18^{*}$ ESSD. Environmentally Sustainable Development Studies and Monographs Series. Washington, D.C., USA: The World Bank. http://documents.worldbank.org/curated/en/1997/06/694732/five-years-after-rio-innovationsenvironmental-policy. 
World Energy Council. 2013. "World Energy Resources: 2013 Survey." London: World Energy Council.

WTO. 1994. Agreement on Subsidies and Countervailing Measures. https://www.wto.org/english/docs_e/legal_e/24-scm_01_e.htm.

Xue, Hao, Hanjie Wang, Richard Bridle, Ivetta Gerasimchuk, and Clement Attwood. 2015. "Subsidies to Coal Production in China." Global Subsidies Initiative. Geneva, Switzerland: International Institute for Sustainable Development (IISD).

Zhang, Yujiang, Guorui Feng, Min Zhang, Hongrui Ren, Jinwen Bai, Yuxia Guo, Haina Jiang, and Lixun Kang. 2016. "Residual Coal Exploitation and Its Impact on Sustainable Development of the Coal Industry in China." Energy Policy 96 (September): 534-41. doi:10.1016/j.enpol.2016.06.033.

\section{Appendix}

\section{Country-by-country assessment of production subsidies}

\section{Australia}

Data on current coal production subsidies in Australia is available from different sources which provide very different estimates: while OECD data suggests an average annual subsidy of 0.1 bn USD (20072014) (OECD 2015a), Fulton, Buckley et al. (2015) assume an average direct tax deductions potential that was available from 2005 to 2011 ( 0.3 bn USD annually), and fuel tax credit scheme available from 2012 to 2013 (0.6 bn USD annually), will both also be available to producers in the future. Additionally, they note that current practice of allowing mining companies to provide less costly financial products as a substitute for rehabilitation bonds, constitute a subsidy to coal mining, which they estimate at 1.5 USD/t or 0.7 bn USD ${ }^{21}$, annually. Makhijani and Doukas (2015) report national subsidies to coal production of 0.3 bn USD, almost exclusively from direct spending. The $76 \%$ of the subsidies are directed towards remediation, while the rest splits between transportation $(20 \%)$, R\&D (3\%) and exploration (1\%). Some of the subsidies apply on the regional level for production in New South Wales $(46 \%)$ and Queensland $(20 \%)$, the remainder applies to all production sites. For the purpose of the analysis in this paper, I employ the conservative values estimated by Makhijani and Doukas (2015), but add the rehabilitation subsidy noted by Fulton et al. (2015), as this constitutes a major subsidy otherwise not covered. The resulting coal production subsidy level is $2.5 \mathrm{USD} / \mathrm{t}$ for New South Wales, $2.1 \mathrm{USD} / \mathrm{t}$ for Queensland, and $1.8 \mathrm{USD} / \mathrm{t}$ for all other regions ${ }^{22}$.

\section{China}

The level of subsidies on coal production in China in 2013 is estimated at 5.8 bn USD excluding 0.6$5.8 \mathrm{bn}$ USD of support granted through tax credits, which translate to 1.5 to $3 \mathrm{USD} / \mathrm{t}$ of coal produced (Xue et al. 2015). These figures also include financial assistance for state-owned enterprises (SOEs) which account for $92 \%$ of coal production in 2013 (Xue et al. 2015). Support is granted as part of an

\footnotetext{
${ }^{21}$ According to IEA (2015b), Australia produced 458 Mt of coal in 2013.

${ }^{22}$ According to Queensland Government (2016) coal production in Queensland totaled on average $226 \mathrm{Mt}$ (20122015); according to the NSW Department of Industry (2015) coal production in New South Wales totaled $196 \mathrm{Mt}$ in 2013-2014.
} 
industry consolidation and infrastructure improvement plan. While, according to Xue et al. (2015), this subsidy totaled 1.3 bn USD in 2013, ODI (2015a) reports an average support of 6.2 bn USD (20132014). For reasons of consistency, I use the figure from Xue et al. (2015). To arrive at figures to be included in this analysis, I further subtract subsidies for coal-bed methane, which is not covered in the model setting, support for R\&D, and oversea investments. Furthermore, I employ the conservative estimate on support through tax credits, which gives a total subsidy level of 4.4 bn USD (originating from state level $(71 \%)$ and regional level (29\%) support). The remainder includes direct payments and investments $(54 \%)$, provision of services below market value $(39 \%)$, and subsidies in the form of foregone profits $(6 \%)$. The resulting calculated subsidy level is $1.4 \mathrm{USD} / \mathrm{t}$ for producers from Shanxi, Shaanxi and Inter Mongolia, and 0.9 USD/t for producers from all other regions ${ }^{23}$.

A sum of 1 bn USD of the subsidies is given as compensation for those coal mines that are shut down due to the coal phase-out plan (Xue et al. 2015), other forms of practiced subsidies require local content or give preferential treatment to state-owned enterprises. According to the definition used in section 3.1 these payments clearly constitute a subsidy. This example highlights the fact that the definition of a subsidy is non-indifferent on whether it is used to remove market failures or not. However, a detailed evaluation of the efficiency of each individual subsidy is beyond the scope of this study.

\section{India}

Data on coal production subsidies in India is only available from Garg and Bossong (2015). They report total average governmental support of 0.8 bn USD for the period 2013-2014 (ODI 2015b). To a small extent, it takes the form of tax breaks and direct funding for exploration, extraction and equipment, but over $90 \%$ originates from investment by SOE Coal India Limited (CIL), which account for around $70 \%$ of total coal production in India. Taking into account the state's share and the market share of CIL support translates in a subsidy of $0.9 \mathrm{USD} / \mathrm{t}$ of coal produced ${ }^{24}$.

\section{Indonesia}

Lontho and Beaton (2015) undertake a comprehensive effort in compiling fossil fuel subsidies in Indonesia, but find little data available for the coal sector. OCl (2015) report annual government support to coal mining of 0.9 bn USD in 2013, mainly originating from a difference in royalty taxes between small and big mines, and from untaxed production, accounting for $12-15 \%$ of annual production (50-90Mt in 2014, Sanzillo 2015). For the royalty tax reforms are announced, but have not been included in any regulation, so far (PwC 2015, 37), and has been impeded by local resistance (Gatot and Sjahrir 2015; Kannan, Das, and Corazon Aureus 2015). Untaxed production is currently targeted by a new policy requiring producers to obtain "clean and clear" certificates (PwC 2015, 10).

\footnotetext{
${ }^{23}$ According to Denjean et al. (2015), in 2013, total coal production in China was $3.7 \mathrm{Gt}$, with Shanxi, Shaanxi, and Inner Mongolia accounting for $0.96 \mathrm{Gt}, 0.493 \mathrm{Gt}$, and $0.994 \mathrm{Gt}$, respectively.

${ }^{24}$ According to IEA (2015b), coal production in India totaled $610 \mathrm{Mt}$ in 2013, and $668 \mathrm{Mt}$ in 2014. CIL is a $90 \%$ SOE (cf. https://www.coalindia.in/en-us/company/structure.aspx).
} 
For coal produced under the Domestic Market Obligation (DMO) consumers pay a regulated price which is benchmarked against a basket of market-based prices (PwC 2015, 10), including an international reference price. Therefore the case for subsidization via price discrimination cannot be clearly made. Assuming that the two policies equalizing the royalty taxes and preventing unmonitored production remain in their current state and do not become effective, Indonesia exhibits a coal production subsidy of $1.8 \mathrm{USD} / \mathrm{t}^{25}$.

\section{Poland}

As Poland is not a G20 country ODI does not provide a country study and thus no fossil fuel subsidy data base. Therefore, the only source that estimates subsidies to coal production in Poland is OECD (2015a). For 2013 and 2014 the data base reports subsidies of 0.76 bn USD which translate to 5.4 USD/t of coal produced using production figures from IEA (2015b). $98 \%$ of the subsidy originates from "stranded cost compensation". However, this compensation is paid to electricity producers to compensate for the termination of long-term power-purchase agreements. In context of the present analysis, this does not constitute a producer subsidy but rather a consumer subsidy as power plants are the consumers of the coal and such subsidies have been excluded in other cases as well. A small fraction of $0.01 \mathrm{bn}$ USD equivalent to a subsidy of $0.1 \mathrm{USD} / \mathrm{t}$ remains, which is attributed to free energy supply for mine workers.

\section{$\underline{\text { Russia }}$}

Data on fossil fuel subsidies is available from Ogarenko et al. (2015) and OECD (2015a). For coal production estimates diverge very significantly, with 0.07 bn USD estimated by the former for 20132014, while the latter reports an average subsidy level of 0.99 bn USD for 2006-2014, and an extreme increase to levels of 2.29 bn USD to 6.04 bn USD for 2013 and 2014. The two sources report very different subsidy levels for the cost items of "Spending on Exploration and Prospecting for Coal" and another item, "Support for Restructuring and Development of the Coal", is missing in the former database. For reasons of consistency, I base the analysis on data from Ogarenko et al. (2015). Accounting for average annual steam coal production in 2013 and 2014, the resulting subsidy level is $0.4 \mathrm{USD} / \mathrm{t}$. The majority of subsidies is directed towards tax benefits on the regional level (52\%), while the rest is used for tax exemptions (33\%) and direct spending (14\%).

\section{South Africa}

Information on coal production subsidies is rarely available for South Africa. Garg and Kitson (2015) report expenditures of 0.04 bn USD to expand coal transportation infrastructure in 2014.

Beside, Eberhard $(2015,180)$ states that Sasol sells underpriced coal to its Coal-to-Liquids $(C t L)$ plant at rates of $12 \mathrm{USD} / \mathrm{t}$ while domestic coal prices are reported to be $20 \mathrm{USD} / \mathrm{t}$ (Eberhard 2015, 196). In the COALMOD-World base case data, production cost for South Africa do not account for this subsidy

\footnotetext{
${ }^{25}$ According to IEA (2015b), Indonesia has produced $487.7 \mathrm{Mt}$ of coal (total of thermal coal and metallurgic coal) in 2013.
} 
and start at $20 \mathrm{USD} / \mathrm{t}$. Therefore, only subsidies to transport infrastructure which is dedicated to export coal are included in the new analysis, which accounts for $0.5 \mathrm{USD} / \mathrm{t}$.

\section{USA}

Data on current coal production subsidies in the US is available from different sources: the reported levels range from $1 \mathrm{bn}$ USD in 2013 reported by EIA (2015a) to 6.8bn USD calculated by Fulton, Buckley et al. (2015). Doukas and Whitley (2015) undertake an extensive review of fossil fuel related subsidies in the US and provide a detailed list by subsidy type, jurisdiction, fuel, and fuel chain stage (ODI 2015c) which extends the effort undertaken by OECD (2015a). They calculate national coal production subsidies of 2.1 bn USD. According to their figures, the largest shares of total subsidies originate from relief of royalties (50\%), and support for extraction (15\%), and remediation (18\%). The data allows differentiating between federal subsidies, which apply to all US coal production (44\%), and state subsidies that only apply to particular basins (subsidies by the state of Wyoming make up $50 \%$ of total subsidy level). Based on this disaggregation, coal production subsidies for the Powder River Basin amount to $3.4 \mathrm{USD} / \mathrm{t}, 1.1 \mathrm{USD} / \mathrm{t}$ for Appalachia and 1.0USD/t for all other basins ${ }^{26}$.

\section{Other producers}

No information on subsidies is available for Colombia, and other smaller coal producers like Venezuela and Mozambique.

\section{Country-by-country assessment of coal reserves in operating mines}

\section{Australia}

Values for Australia are based on information from Geosience Australia (Britt et al. 2015) which report $19816 \mathrm{Mt}$ reserves of black coal in operating mines. Mine level information is available from Australian Mines Atlas ${ }^{27}$ but could not be used due to a lack of reporting by some companies.

\section{China}

The Statistical Yearbook 2014 (NBSC 2016, Table 8.5) reports ensured reserves by region for 2013, which sum up to a total of $236290 \mathrm{Mt}$. To arrive at a number on recoverable reserves the figure is corrected by the average recovery factor of $48 \%$ obtained from Zhang et al. (2016). Data on reserves in producing mines could not be obtained, as there seems to be no obligation to publish such information to the general public. Therefore, numbers are calculated based on the ratio of reserves reported by BGR (2015) to reserve in operating mines directly obtained from literature (for USA,

\footnotetext{
${ }^{26}$ According to EIA (2016), US coal production totaled 984 Mt (short) in 2013 and 1000 Mt (short) in 2014; Wyoming had an average share of $39 \%$, West Virginia (11\%) and Kentucky (8\%). Federal level subsidies that apply to all production sites account for $44 \%$ of the totals, while West Virginia and Kentucky account for $4 \%$ and $2 \%$, respectively; the remained stems from Wyoming state support. Furthermore, the calculation takes into account the share of Wyoming of total PRB production (86\%) and the share of Kentucky and West Virginia in total Appalachia production (65\%).

${ }^{27} \mathrm{http}: / /$ www.australianminesatlas.gov.au/?site=atlas\&tool=search.
} 
Colombia, Poland, South Africa, Indonesia, and Australia). The number in brackets is based on the highest ratio obtained in South Africa (69\%), while the standard assumption is the average ratio (33\%).

\section{Colombia}

For Colombia, data on coal reserves in operating mines is obtained from the annual reports of the operating companies which were available for Cerrejon, Calenturitas, and La Jagua from Glencore (2016, 59). The operator Caribbean Resources Corp. provides only resource estimates for its mines Cerro Largo (11.6-21.2 Mt), and La Caypa $(47 \mathrm{Mt})^{28}$. The operator Drummond Company does not provide any data on reserves, instead estimates from the Global Methane Initiative (EPA 2015a, 85) where used for La Loma (485 Mt), and El Descanso (960 Mt). No data was found for La Francia and Jam. In total, $3221 \mathrm{Mt}$ of reserves are estimated in operating mines in Colombia.

\section{India}

On the one hand, information on coal reserves in India is readily available from the Coal Directory of India Coal statistics Controller's Organisation (2015), differentiated by depth, quality, and certainty, on a field-wise level. On the other hand, this data carries high uncertainty and measurement is not in line with international standards. Fernandes and Sanzillo (2013) report that reserve estimates for Coal India Limited (CIL), India's largest, state-owned coal company are $17 \%$ overestimated because of categorization based on India ISP code, instead of the international common UNFC code. Cmpdi (2014) provides estimates of category $\mathrm{G} 1$ reserves $^{29}$ of $19805 \mathrm{Mt}$ of mineable coal in operating mines. This number excludes reserves in captive mining blocks that where allocated to private and public companies. Reserves in these deposits are only available from the Coal Directory of India Coal statistics (2015), reported at $34419 \mathrm{Mt}$. Applying the same correction factor as for coal from CIL deposits gives a total of $48373 \mathrm{Mt}$. Currently, the allocation of all these blocks except for four was found illegal and arbitrary by the Indian supreme court in 2014 (Rajagopal 2014). The court ruled that the central government has to re-auction these blocks or has to collect adjustment payments instead. I assume that these blocks remain undistributed as an extreme assumption, resulting in the difference between the high and the low estimate reported for India.

It is worth noting that a significant share $(24 \%)$ of India's coal reserves are in low quality coal with an energy content of $4600 \mathrm{Kcal} / \mathrm{Kg}$ and below (see Table 2.5, Coal Controller's Organisation 2015). Assuming that India will pursue modernizing its coal power plant fleet to achieve higher efficiency and lower specific local and global emissions, it will need to rely on higher quality reserves, which would render low quality deposits stranded.

\footnotetext{
${ }^{28}$ http://www.caribbeanresources.ca/Properties/Map-of-Properties/default.aspx

${ }^{29}$ Defined as: feasibility study (F1) has been made and economically viable (E1). The balance Mineable Reserve (excluding that of losing mines) as on date will be in this category (cmpdi 2014, 9)
} 


\section{Indonesia}

For Indonesia, active mining operations were identified by assessing the Mining Atlas ${ }^{30}$ with limited free access. A mine-by-mine assessment was performed based on company annual reports and other publicly available data. Some sources do not distinguish between proven and probable reserves. Total reserves in operating mines are estimated to be $3.5 \mathrm{Gt}$ as of end of 2015.

\section{Kazakhstan}

For Kazakhstan no data on reserves in operating mines could be found. The World Energy Council (2013) reports recoverable reserve of hard coal of $21.5 \mathrm{Gt}$ assuming the same ratio between estimated reserves and reserves in operating mines as estimated for Ukraine and Russia (Ukraine: 2500/(15351+16577); Russia: 17700/(49088+97472), resulting in on average 10\%). Therefore, reserves in active mines are estimated at $2.2 \mathrm{Gt}$.

\section{Poland}

Saboczyk and Salagua (2013) compare reserve estimates obtained from using the Polish methodology for reserve assessment to estimates based on the JORC code. They report $0.8 \mathrm{Gt}$ of coal in operating mines under valid concessions.

\section{$\underline{\text { Russia }}$}

According to SUEK (2011), the largest Russian coal producers, the company's proven and probable reserves in operating mines totaled $5.9 \mathrm{Gt}$ by April 2011 . The company accounts for $33 \%$ of coal production in Russia in 2011 (Tazazanov 2012). For other major Russian coal companies no data on reserves was publicly available. To estimate total reserves, I assume that reserves are evenly distributed among the Russian coal mining companies; therefore I assume that SUEK holds $33 \%$ of coal reserves in operating mines. This gives a total estimate of $17.7 \mathrm{Gt}$.

\section{South Africa}

Using data from Wood Mackenzie, SACRM reports reserves of operating mines at $8.9 \mathrm{Gt}$ in 2010, with $95 \%$ of this being thermal coal and the remainder metallurgical in operating mines (SACRM 2011): Low initial coal quality requires washing and beneficiation before coal can be marketed, and $21-24 \%$ of initial mined run-of-mine coal is discarded (SACRM 2011). Accounting for discard, the remaining steam coal reserves in operating mines are estimated at $6.8 \mathrm{Gt}$.

\section{Ukraine}

Due to a lack of available reserve data from the majority of coal mining companies, a similar approach as in the case of Russia is chosen for Ukraine. DTEK reports commercial coal reserves of $1.7 \mathrm{Gt}$ as of 01.01.2015 (DTEK 2014). The company currently produced $46 \mathrm{Mt}$ of coal in 2014, which accounts for $69 \%$ of total production in Ukraine reported by DTEK. Numbers on annual production might be significantly reduced, due to the armed conflict in Ukraine, especially in the largest coal production

\footnotetext{
${ }^{30} \mathrm{https} / / /$ mining-atlas.com/operation/php.
} 
region Donetsk. Due to a lack of other sources, this number is used to scale up reserve figures to 2.5 Gt.

\section{$\underline{\text { USA }}$}

Figures on estimated recoverable reserves are reported as $232017 \mathrm{Mt}$ (255755 short Mt) in EIA (2016, Table 15). Figures on reserves in operating mines are given as $17555 \mathrm{Mt}$ (19351 short Mt) in EIA (2016) based on data from EIA (2016, Table 14).

\section{Other small producers}

For other, small producers, the original entry for estimated reserves from the COALMOD-World data base (see Mendelevitch et al. forthcoming) is used, as they will not have a major influence on international trade patterns, prices and emissions, due to their insignificant size.

\section{Further results of scenario with high estimate of reserves in operating mines}

Table 5: Cumulative production in reference case and scenario with high estimate of reserves in operating mines (in $\mathrm{Mt}$ ).

\begin{tabular}{|c|c|c|c|c|c|c|c|}
\hline \multicolumn{4}{|c|}{ Cumulative production [Mt] } & \multicolumn{4}{|c|}{ 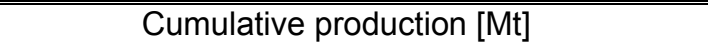 } \\
\hline Country & $\begin{array}{l}\text { Reference } \\
\text { case }\end{array}$ & M\&E Scenario & Change in & Country & $\begin{array}{l}\text { Reference } \\
\text { case }\end{array}$ & $\begin{array}{l}\text { M\&E } \\
\text { Scenario }\end{array}$ & Change in \\
\hline AUS & 6.4 & 8.5 & 33 & POL & 1.9 & 0.8 & -58 \\
\hline $\mathrm{CHN}$ & 89.7 & 83.7 & -7 & RUS & 6.6 & 10.0 & 52 \\
\hline COL & 4.9 & 3.2 & -35 & UKR & 1.5 & 2.1 & 40 \\
\hline IDN & 13.0 & 6.1 & -53 & USA & 32.3 & 14.9 & -54 \\
\hline IND & 30.1 & 26.9 & -11 & VEN & 0.5 & 0.5 & 0 \\
\hline KAZ & 3.5 & 2.2 & -37 & VNM & 0.2 & 0.2 & 0 \\
\hline MNG & 1.2 & 1.2 & 0 & ZAF & 12.0 & 6.8 & -43 \\
\hline MOZ & 0.2 & 0.2 & 0 & Total & 204.0 & 167.3 & -18 \\
\hline
\end{tabular}




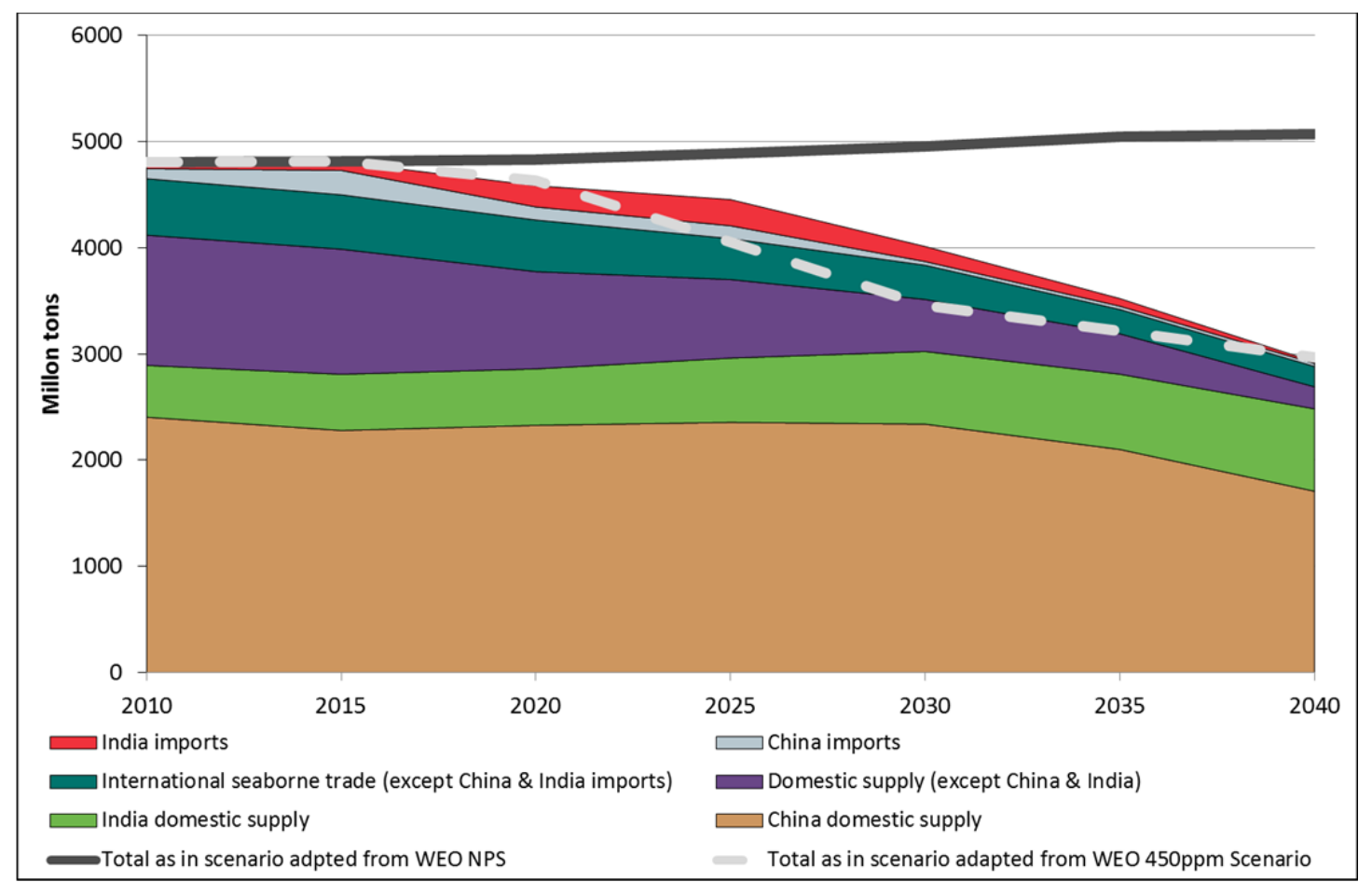

Figure 3: Total supply from imports and domestic production in scenario with high estimate of reserves in operating mines (in Mtpa). 


\section{Further details and results of the M\&E scenario}

Table 6: Cumulative production in reference case and M\&E scenario (in Mt).

\begin{tabular}{|c|c|c|c|c|c|c|c|}
\hline \multirow[b]{2}{*}{ Country } & \multirow{2}{*}{$\begin{array}{l}\begin{array}{l}\text { Cumulative } \\
{[\mathrm{Mt}]}\end{array} \\
\text { Reference } \\
\text { case }\end{array}$} & \multirow{2}{*}{\begin{tabular}{l}
\multicolumn{2}{c}{ production } \\
M\&E \\
Scenario
\end{tabular}} & \multirow[b]{2}{*}{$\begin{array}{l}\text { Change in } \\
\%\end{array}$} & \multirow[b]{2}{*}{ Country } & \multicolumn{2}{|c|}{ Cumulative production $[\mathrm{Mt}]$} & \multirow[b]{2}{*}{$\begin{array}{l}\text { Change in } \\
\%\end{array}$} \\
\hline & & & & & $\begin{array}{l}\text { Reference } \\
\text { case }\end{array}$ & $\begin{array}{l}\text { M\&E } \\
\text { Scenario }\end{array}$ & \\
\hline AUS & 6447 & 4000 & -38 & POL & 1916 & 2505 & 31 \\
\hline $\mathrm{CHN}$ & 89723 & 50113 & -44 & RUS & 6645 & 3970 & -40 \\
\hline COL & 4865 & 3521 & -28 & UKR & 1455 & 940 & -35 \\
\hline IDN & 13000 & 11850 & -9 & USA & 32291 & 13001 & -60 \\
\hline IND & 30146 & 10916 & -64 & VEN & 479 & 479 & 0 \\
\hline KAZ & 3481 & 2090 & -40 & VNM & 150 & 150 & 0 \\
\hline MNG & 1170 & 1170 & 0 & ZAF & 12033 & 2788 & -77 \\
\hline MOZ & 212 & 212 & 0 & Total & 204013 & 107705 & -47 \\
\hline
\end{tabular}

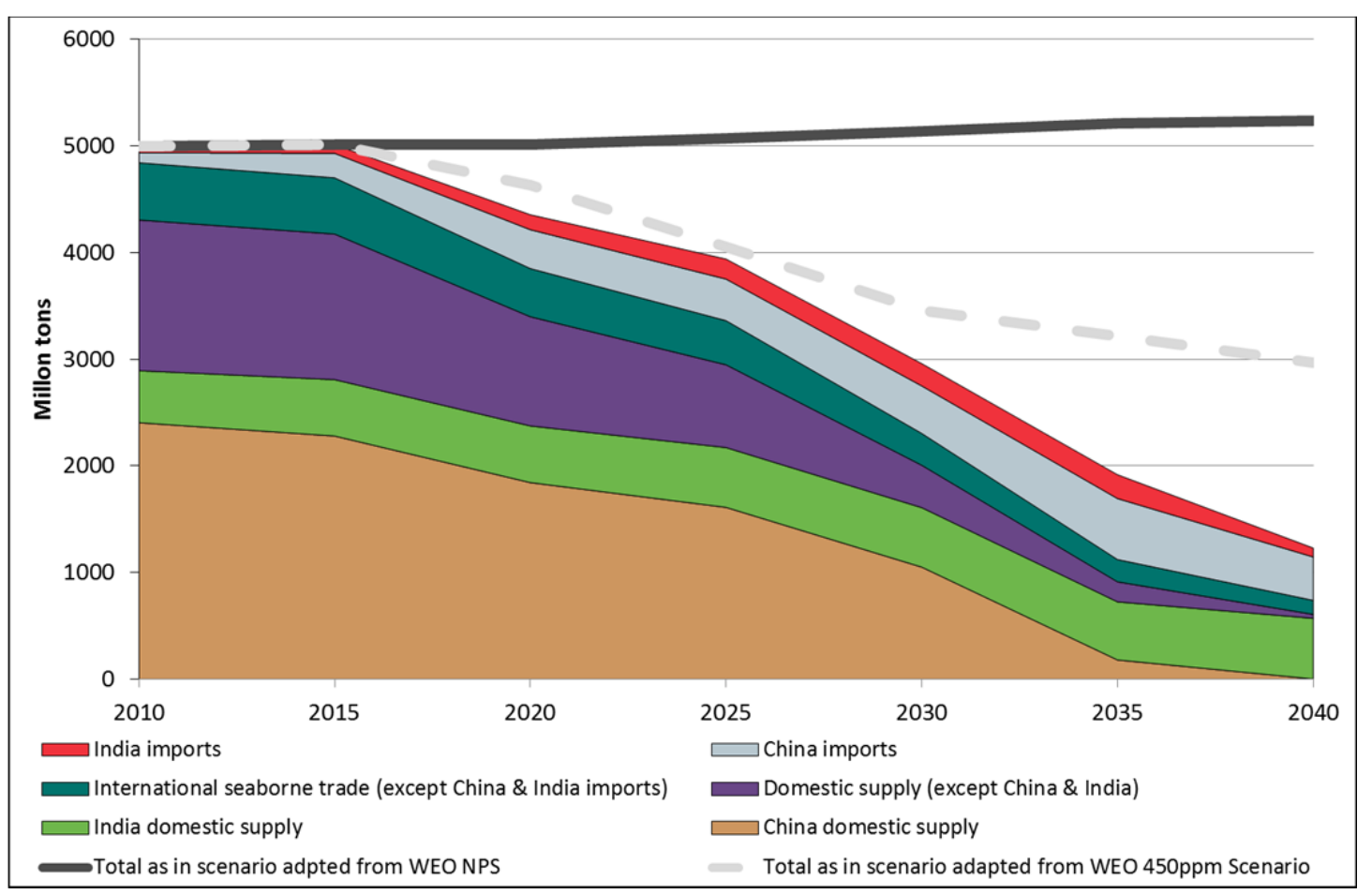

Figure 4: Total supply from imports and domestic production in M\&E scenario (in Mtpa).

Conversion between reserves and resources data from McGlade and Ekins (2015) and COALMOD-World

There is no perfect match between the data provided by McGlade and Ekins (2015) (M\&E) and data from the COALMOD-World (CMW) dataset. While TIAM-UCL, the model used by M\&E, is an energy systems model, CMW is a sectoral model. Additionally, the two models have different time horizons: TIAM-UCL calculates energy use until 2100, with levels of resources unburned reported until 2050.

The two models also have different spatial coverage. While the first has a global coverage of both the demand and the supply of fossil resources, the second is focused on international trade aspects and 
therefore has no representation of purely self-supplying countries. Therefore, both supply and demand estimates are lower in COALMOD-World as compared to TIAM-UCL.

Moreover, M\&E's definition of hard coal also includes coking coal, while CMW is focused on steam coal only, which increases hard coal demand in M\&E compared to CMW. Additionally, M\&E overestimates the use of lignite compared to hard coal (cf. BGR (2015): hard coal production in 2014: $7.15 \mathrm{Gt}$, Lignite: $1.05 \mathrm{Gt}$, compared to $4.9 \mathrm{Gt}$ hard coal and $3.6 \mathrm{Gt}$ lignite calculated by M\&E). One explanation for this divergence might be that M\&E overestimate the mobility of lignite which is only used for local electricity production due to its low energy content per volume and tonnage ratio, in reality. This might lead to an overestimation of unburned hard coal reserves in M\&E. To be consistent with other literature (e.g., Finighan 2016), I use estimates on shares of unburned coal reserves, which comprise hard coal and lignite, for my scenario calculations.

For neither of the issues discussed above there is an easy fix or work-around. As many other measurement errors are also inherent to both model datasets, the results of the scenario should be interpreted as approximate values. 
Table 7: Production capacity and reserves in COALMOD-World dataset and M\&E scenario.

\begin{tabular}{|c|c|c|c|c|c|c|}
\hline & & $\begin{array}{l}\text { Production } \\
\text { Cap. in } \\
\text { COALMOD- } \\
\text { World }\end{array}$ & $\begin{array}{l}\text { Reserves in } \\
\text { COALMOD- } \\
\text { World }\end{array}$ & Scenario & $\begin{array}{l}\text { M\&E Scenario } \\
\text { values for coal } \\
\text { reserves burned } \\
\text { until } 2050\end{array}$ & Comments \\
\hline & P_USA_PRB & 525 & 112555 & 6469 & 12 Gt for USA & Distribution based on current production levels \\
\hline & P_USA_Rocky & 79 & 20704 & 973 & same as above & same as above \\
\hline & P_USA_ILL & 115 & 82887 & 1419 & same as above & same as above \\
\hline USA & P_USA_APP & 336 & 54572 & 4140 & same as above & same as above \\
\hline Colombia & $\mathrm{P}_{-}^{-} \mathrm{COL}^{-}$ & 75 & 6229 & 3521 & 4 Gt for CSA & Distribution ensures usage of Venezuela reserves \\
\hline Venezuela & P_VEN & 10 & 479 & 479 & same as above & same as above \\
\hline Poland & P_POL & 71 & 13997 & 9000 & 9 Gt for Europe & \\
\hline Ukraine & $\mathrm{P}_{-}^{-} \mathrm{UKR}$ & 45 & 16271 & 940 & 7 Gt for FSU & Distribution based on current production levels \\
\hline Kazakhstan & $P_{-}^{-} \mathrm{KAZ}$ & 100 & 28145 & 2090 & same as above & same as above \\
\hline Russia & $P_{-}$RUS & 190 & 49078 & 3970 & same as above & same as above \\
\hline \multirow{4}{*}{ South Africa } & P_ZAF & 267 & 48740 & 2788 & 3 Gt for Africa & Distribution ensures usage of Mozambique reserves \\
\hline & P_IND_North & 281 & 35663 & 6169 & $\begin{array}{l}62 \text { for India and } \\
\text { China }\end{array}$ & $\begin{array}{l}\text { Distribution based on current reserves and ensures usage of } \\
\text { Mongolia reserves }\end{array}$ \\
\hline & P_IND_Orissa & 123 & 14416 & 2494 & same as above & same as above \\
\hline & P_IND_West & 53 & 7134 & 1234 & same as above & same as above \\
\hline \multirow[t]{2}{*}{ India } & P_IND_South & 58 & 6755 & 1169 & same as above & same as above \\
\hline & P_VNM & 62 & 150 & 150 & $\begin{array}{l}12 \text { Gt for Other } \\
\text { developing Asia }\end{array}$ & Distribution ensures usage of Vietnam reserves \\
\hline \multirow[t]{4}{*}{ Indonesia } & P_IDN & 340 & 13000 & 11850 & same as above & same as above \\
\hline & P_CHN_SIS & 1573 & 213400 & 36916 & $\begin{array}{l}62 \text { for India and } \\
\text { China }\end{array}$ & $\begin{array}{l}\text { Distribution based on current reserves and ensures usage of } \\
\text { Mongolia reserves }\end{array}$ \\
\hline & P_CHN_Northeast & 121 & 15900 & 2750 & same as above & same as above \\
\hline & P_CHN_HSA & 564 & 4700 & 4700 & & used up until 2020 , before policy is introduced \\
\hline \multirow[t]{2}{*}{ China } & $\mathrm{P}_{-}^{-} \mathrm{CHN} \mathrm{N}_{-}^{-} \mathrm{YG}$ & 450 & 36800 & 6366 & same as above & same as above \\
\hline & P_AUS_QLD & 85 & 24764 & 1667 & 4 for OECD Pacific & Distribution based on current production capacity \\
\hline \multirow[t]{2}{*}{ Australia } & P_AUS_NSW & 119 & 13829 & 2333 & same as above & same as above \\
\hline & $\mathrm{P}_{-} \mathrm{MNG}$ & 17 & 1170 & 202 & $\begin{array}{l}62 \text { for India and } \\
\text { China }\end{array}$ & $\begin{array}{l}\text { Distribution based on current reserves and ensures usage of } \\
\text { Mongolia reserves }\end{array}$ \\
\hline Mozambique & $\mathrm{P} \_\mathrm{MOZ}$ & 5 & 212 & 212 & $3 \mathrm{Gt}$ for Africa & Distribution ensures usage of Mozambique reserves \\
\hline
\end{tabular}

Source: Own calculation based on reserves and production data from Holz et al. (2015), and McGlade and Ekins (2015). 